\title{
Flood dispersal and deposition by near-bed gravitational sediment flows and oceanographic transport: A numerical modeling study of the Eel River shelf, northern California
}

\author{
Courtney K. Harris \\ Virginia Institute of Marine Science, ckharris@vims.edu \\ Peter A. Traykovski \\ Woods Hole Oceanographic Institution \\ W. Rockwell Geyer \\ Woods Hole Oceanographic Institution
}

Follow this and additional works at: https://scholarworks.wm.edu/vimsarticles

Part of the Marine Biology Commons

\section{Recommended Citation}

Harris, Courtney K.; Traykovski, Peter A.; and Geyer, W. Rockwell, "Flood dispersal and deposition by nearbed gravitational sediment flows and oceanographic transport: A numerical modeling study of the Eel River shelf, northern California" (2005). VIMS Articles. 278.

https://scholarworks.wm.edu/vimsarticles/278 


\title{
Flood dispersal and deposition by near-bed gravitational sediment flows and oceanographic transport: A numerical modeling study of the Eel River shelf, northern California
}

\author{
Courtney K. Harris \\ Department of Physical Sciences, Virginia Institute of Marine Science, Gloucester Point, Virginia, USA
} Peter A. Traykovski and W. Rockwell Geyer
Applied Ocean Physics and Engineering Department, Woods Hole Oceanographic Institution, Woods Hole, Massachusetts,
USA

Received 24 September 2004; revised 25 February 2005; accepted 27 June 2005; published 30 September 2005.

[1] A large flood of the Eel River, northern California, created a thick sediment deposit between water depths of 50 and $70 \mathrm{~m}$ in January 1997. The freshwater plume, however, confined sediment delivery to water depths shallower than $30 \mathrm{~m}$. Mechanisms proposed to explain the apparent cross-shelf transport include dispersal by oceanographic currents, resuspension by energetic waves, and gravitationally forced transport of a thin layer of fluidized mud. Field observations indicate that these processes were all active but cannot determine their relative significance or whether these mechanisms alone explain the location, size, and timing of deposition. Approximately 30\% of the sediment delivered by the Eel River is accounted for in the midshelf mud bed and inner shelf, but the fate of the remaining $70 \%$ is uncertain. A three-dimensional, hydrodynamic model was used to examine potential mechanisms of sediment transport on the Eel River shelf. The model includes suspended sediment transport and was modified to account for a thin, near-bed layer of fluidized mud. It was used to simulate flood dispersal on the Eel River shelf, to compare the relative importance of transport within the near-bed fluid mud layer to suspended sediment transport, and to evaluate sediment budgets for floods. Settling properties of fine-grained sediment, both within the flood plume and the fluid mud layer, critically impact depositional patterns. To a lesser degree, wind-driven ocean currents influence the volume of sediment that escapes the shelf, and wave magnitude affects the cross-shelf location of flood deposits. Though dilute suspension accounts for a large fraction of total flux, cross-shelf transport by gravitational forcing appears necessary to produce a midshelf mud deposit similar in volume, location, and timing to those seen offshore of the Eel River.

Citation: Harris, C. K., P. A. Traykovski, and W. R. Geyer (2005), Flood dispersal and deposition by near-bed gravitational sediment flows and oceanographic transport: A numerical modeling study of the Eel River shelf, northern California, J. Geophys. Res., 110, C09025, doi:10.1029/2004JC002727.

\section{Introduction}

[2] Seabeds off of major rivers on the U.S. Pacific coast, including the Columbia, Eel, and Russian Rivers, commonly exhibit distinct midshelf mud deposits that can be traced to fluvial sources [see, e.g., Griggs and Hein, 1980; Nittrouer and Sternberg, 1981; Field et al., 1992; Sommerfield and Nittrouer, 1999]. The emplacement of these has been explained by sediment raining out of the buoyant river plume during floods, whereby the plume itself delivered the sediment to the midshelf depocenter [Nittrouer and

Copyright 2005 by the American Geophysical Union. 0148-0227/05/2004JC002727
Sternberg, 1981; Kachel and Smith, 1986, 1989; Nittrouer and Wright, 1994].

[3] Evidence from the Eel River shelf in northern California (see Figure 1) contradicts these explanations, as was learned during the STRATA Formation on Margins (STRATAFORM) program [see Nittrouer, 1999]. Hydrographic surveys conducted during large floods of the Eel River showed that sediment delivery from the river plume was confined to the inner shelf ( $<30 \mathrm{~m}$ water depth). The discrepancy between delivery by the plume and the midshelf mud bed implies that substantial cross-shelf transport occurs during, or soon after, sediment delivery by floods [Geyer et al., 2000]. Mechanisms proposed to explain the apparent cross-shelf transport include dispersal by oceano- 
(A) Eel River Shelf Bathymetry

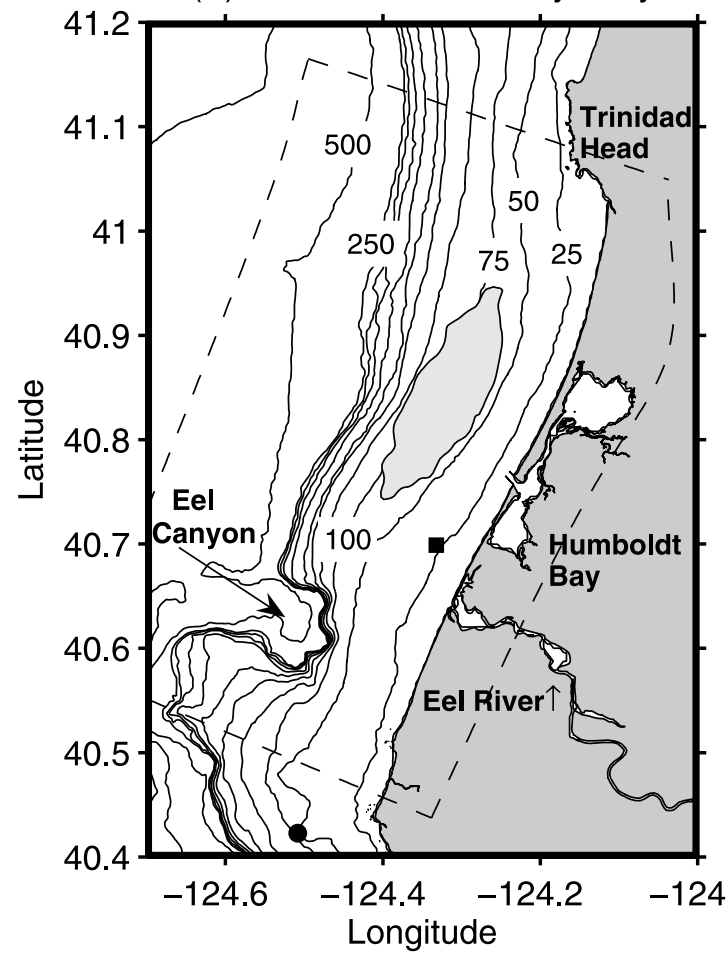

(B) Model Grid

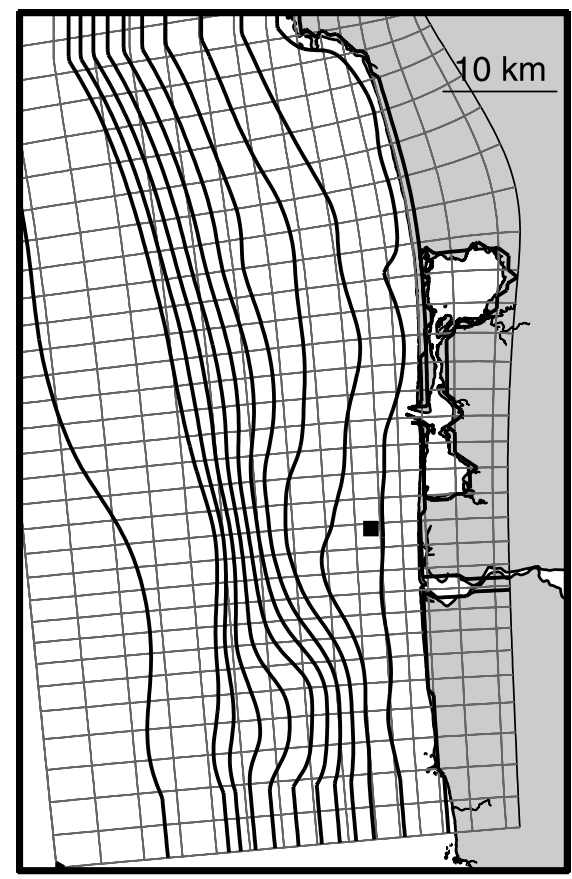

Figure 1. (a) Eel River shelf study area and (b) model grid. Bathymetric contours are drawn every $25 \mathrm{~m}$ up to $250 \mathrm{~m}$ and then drawn at $500-\mathrm{m}$ intervals. Squares show the locations where sediment flux is evaluated in Figures 10 and 11. Circle in Figure 1a is location of National Oceanographic Data Center (NODC) Buoy 46030. In Figure 1a, shaded patch shows location of flood deposition from 1995 and 1997 floods of the Eel River as identified by Sommerfield and Nittrouer [1999] and Wheatcroft and Borgeld [2000]. Extent of model grid is shown with dashed lines. Bathymetry is from National Geophysical Data Center [2003]. In Figure 1b, model grid with smoothed bathymetry used for simulations, where each grid cell illustrated represents 25 model grid points.

graphic currents, resuspension by energetic waves, and gravitationally forced transport of a thin layer of fluidized mud.

\subsection{Observations From the Eel River Shelf}

[4] Observations made during a flood in 1997 provided a rare opportunity to chronicle the emplacement of a preservable continental shelf event bed. On 1 January 1997, Eel River discharge at Scotia, California, peaked at $11,200 \mathrm{~m}^{3} / \mathrm{s}$ (Figure 2), the fifth largest of the 93-year record (19102003). This flood delivered an estimated $34-45 \times 10^{9} \mathrm{~kg}$ of sediment to the shelf, of which $\sim 6.7 \times 10^{9} \mathrm{~kg}( \pm 15 \%)$ was deposited on the midshelf [Wheatcroft and Borgeld, 2000]. Two weeks after the maximum discharge, flood deposits were centered between 50- and 90-m water depths (see Figure 1a), with peak thicknesses of $\sim 6 \mathrm{~cm}$ [Sommerfield et al., 1999; Wheatcroft and Borgeld, 2000]. Over both short (a few weeks) and 100-year timescales, the midshelf mud deposit accounts for $\sim 20 \%$ of the fine-grained sediment delivered by the Eel River [Sommerfield and Nittrouer, 1999].

[5] Tripod observations imply that cross-shelf transport from the inner shelf can deliver sediment to the midshelf depocenter by gravitationally forced transport of a thin layer of fluidized mud [Traykovski et al., 2000]. Turbulence within the wave boundary layer allows it to hold large amounts of suspended sediment. Stable stratification caused by the increased density near the bed and decrease in turbulence at the height of the wave boundary layer traps sediment within the thin, near-bed layer. At high concentrations, the turbid layer flows downslope. Such transport was seen at multiple sites on the shelf, during several flood and storm events [Ogston et al., 2000; Traykovski et al., 2000].

[6] On the basis of mass balance estimates, the fate of $\sim 70 \%$ of sediment delivered to the Eel shelf is unknown, with the retention of $20 \%$ in the mud deposit and $6-13 \%$ on the inner shelf [Sommerfield and Nittrouer, 1999; Wheatcroft and Borgeld, 2000; Crockett and Nittrouer, 2004]. Some of the discrepancy between delivery and retention may be explained by uncertainties in the river's sediment load, which was not measured in 1997. Other loss terms include sediment exported to the north, south, and offshore. Sediment from the Eel River catchment has been identified in deposits on the Oregon and Washington shelves, hundreds of kilometers from the source [Karlin, 1980]. Transport to the Eel Canyon seems to account for at least $12 \%$ of the sediment budget [Mullenbach et al., 2004]. A small fraction of sediment is transported off shelf as resuspended load [Walsh and Nittrouer, 1999; McPhee-Shaw et al., 2004], but it is possible that near-bed gravity flows carry sediment to the continental slope. These exports have been difficult to quantify, however, 

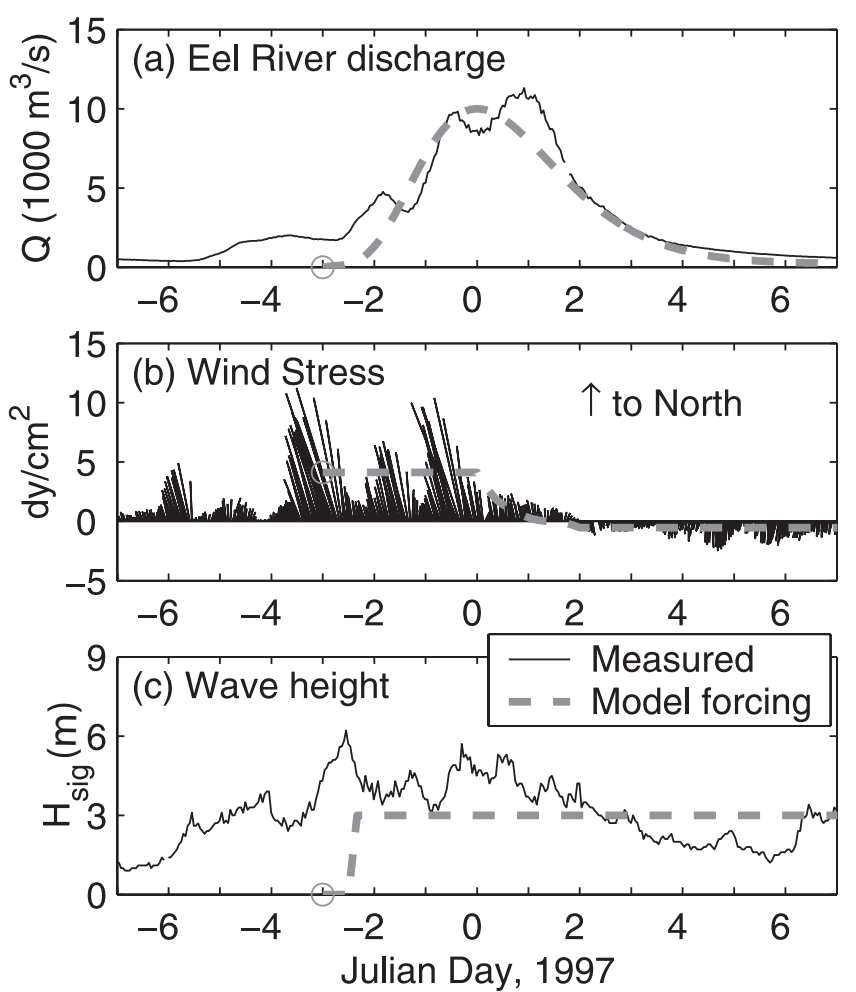

Figure 2. Observed conditions during December 1996 and January 1997 and idealized values used to force numerical model. Time series of (a) Eel River discharge at Scotia, California (U.S. Geological Survey station 11477000), (b) wind stress based on observations of wind speed at NODC Buoy 46030 (see Figure 1 for location), and (c) wave height measured by NODC Buoy 46030. Measured values are shown as solid lines. Idealized conditions (dashed lines) were used to drive numerical model.

and the sediment budget for material delivered by the Eel River has never truly been closed.

[7] The relative importance of near-bed gravitationally forced transport compared to water column suspended transport has not been addressed with sufficient resolution. Observations have been limited to measurements made at a few locations on the continental shelf [Ogston et al., 2000; Traykovski et al., 2000]. These showed that up to $80 \%$ of cross-shelf sediment flux could be attributed to gravitationally driven transport during and after periods of high river discharge [Traykovski et al., 2000].

\subsection{Models of the Eel River Shelf}

[8] Numerical and analytical models that relate observable water column transport to stratigraphic signature for the Eel shelf complemented STRATAFORM observational studies [Cacchione et al., 1999; Reed et al., 1999; Zhang et al., 1999; Harris and Wiberg, 2001, 2002; Scully et al., 2002, 2003; Fan et al., 2004]. These included one or two dimensions, neglecting the three dimensionality of sediment delivery and dispersal. Most considered only a subset of the transport processes known to operate on the Eel shelf either by neglecting gravitationally driven flow [Harris and Wiberg, 2001, 2002], or by neglecting conventional suspended transport [Scully et al., 2002, 2003]. While Scully et al. [2003] correctly predict the location and size of the deposit, they rely on estimates of the amount of the fluvial load that reaches the bottom boundary layer. Their model cannot assess the dispersal of sediment by suspended transport. As a result, for large floods or during times of low wave energy, it overpredicts sediment deposition inshore of the 50-m isobath [Scully et al., 2003]. Thus none of the available models includes all of the processes necessary to close the sediment budget of the Eel shelf or mechanistically test hypothesis of mud bed formation.

\subsection{Objectives}

[9] This paper examines the relative importance of dilute suspended and gravity-driven fluid mud transport on the Eel shelf using a numerical model that incorporates both mechanisms. As a key element, the model includes a near-bed turbid layer that flows downslope through gravitational forcing. The model is used to reproduce depositional patterns for a single flood, that of January 1997, discussed above. The performance of the model, compared to field observations, tests whether the identified processes control dispersal, and whether the conceptual and theoretical basis of the model are sound. Calculated fluxes are evaluated to determine the relative significance of both dilute suspended transport and gravitationally driven transport of fluid muds. The model is further used to explore hypotheses concerning the sediment budget for the event, and to test the sensitivity of calculations to environmental forcing and model parameters.

\section{Methods}

[10] The Estuarine and Coastal Ocean Model-Sediment (ECOM-SED), a version of the Princeton Ocean Model (POM) [see Blumberg and Mellor, 1987] was applied to the Eel River shelf, northern California. ECOM-SED, which includes suspended sediment transport, was modified to account for gravitationally driven transport of a thin, nearbed layer of fluidized mud [Harris et al., 2004]. Estimates of suspended sediment flux, settling, deposition, and erosion were made for an idealized representation of the January 1997 flood (Figure 2). Calculations were run in two modes; the first neglects gravitationally driven transport in the nearbed turbid layer, while the second includes it. This section briefly describes the model's representation of hydrodynamics, sediment transport, and the floods considered.

[11] The model grid used for this study was based on smoothed bathymetry for the Eel shelf (Figure 1b). As described by Harris et al. [2004], the bottom boundary condition was modified in the version that accounts for a near-bed turbid layer. Other than this, hydrodynamic calculations were completed in a standard manner.

\subsection{Suspended Sediment Calculations}

[12] Calculations were limited to the dispersal of finegrained silts and clays to meet the objective of predicting formation of the midshelf mud bed. Simulations assumed that the Eel River provides the only source of mobile sediment. Separate calculations were completed for two sediment types; material that travels as single grains and settles at $0.01 \mathrm{~cm} / \mathrm{s}$, and flocculated material that settles at $0.1 \mathrm{~cm} / \mathrm{s}$. The amounts of each type input to the ocean were 
based on observations and calculations by Geyer et al. [2000] and Hill et al. [2000]. At the bottom boundary, sediment was exchanged between the bottom-most sigma layer of the water column and either the seabed or waveboundary layer at a rate determined by the difference between settling and upward diffusion.

[13] For the case that neglected gravitationally forced transport, the bottom boundary condition follows a modification of van Rijn [1984] adapted by ECOM-SED. This estimates a depth-integrated sediment flux by assuming a parabolic eddy viscosity to specify concentration and velocity, adjusted for sediment stratification. It then sets $Q_{d i}=U C_{s}$; where $Q_{d i}$ is depth integrated flux, and $C_{s}$ and $U$ are representative sediment concentration and velocity. At each time step, this flux estimate is updated and compared to the flux obtained by multiplying the model's estimate of concentration $\left(C_{s, K b}\right)$ and velocity $\left(U_{K b}=\sqrt{\left(u_{K_{b}}^{2}+v_{K_{b}}^{2}\right)}\right)$, where the $K_{b}$ indicates the bottom sigma layer. The suspended sediment concentration of the bottom-most grid cell is then nudged toward the value needed to match the depth-integrated flux; $C_{s, K_{b}}^{\text {new }}=Q_{d i} / U_{K_{b}}$. If $C_{s, K_{b}}^{\text {new }}>C_{s, K_{b}}$ sediment settles to the bed at a vertical flux equal to $w_{s} C_{s, K_{b}}$. If $C_{s, K_{b}}^{\text {new }}<C_{s, K_{b}}$ sediment is eroded from the bed. In this manner, the bottom boundary condition depends on sediment availability, near-bed velocities, sediment properties, and bed shear stress.

\subsection{Gravitationally Forced Transport}

[14] Estimates of gravitationally forced transport are based on a one-dimensional model consistent with observations by Traykovski et al. [2000] of velocities and concentrations of thin fluid muds. These layers were observed on the Eel River shelf to be about the same thickness as the wave boundary layer [Traykovski et al., 2000]. Our model uses a separate grid cell to represent the wave boundary layer $\left(\delta_{w}=u_{* c w} / \omega \sim 0-20 \mathrm{~cm}\right.$ thick), allowing it to account for stratification between the near-bed wave boundary layer and overlying water.

[15] In place of the methods described for conventional suspended transport (section 2.1), the bottom boundary condition for the fluid mud is set as follows. Exchange between the wave boundary layer and the seabed is

$$
E-D=w_{s, \mathrm{wbl}}\left(C_{\mathrm{ref}}-c_{\mathrm{wbl}}\right)
$$

where $E$ and $D$ are erosion and deposition rates $\left(\mathrm{g} /\left(\mathrm{m}^{2} \mathrm{~s}\right)\right)$, respectively. Here, $C_{\text {ref }}$ is an equilibrium concentration estimated following Smith and McLean [1977], and $w_{s, w b l}$ is settling velocity assumed for the fluid mud. If the critical shear stress for motion and erosion are not both exceeded $\left(u_{* c w}<u_{* c r}\right.$, or $\left.u_{* c w}<w_{s, \mathrm{wbl}}\right), C_{\text {ref }}$ is set equal to zero. An upper limit of $C_{\text {ref }}=200 \mathrm{~g} / \mathrm{L}$ was applied, based on the assumption that turbulence would be suppressed at higher concentrations [Trowbridge and Kineke, 1994].

[16] Entrainment of sediment out of the wave boundary layer and into the overlying fluid is estimated using an eddy viscosity modified by a gradient Richardson number. The time-averaged velocity within the wave boundary layer is estimated using a Chezy balance. The velocity therefore depends on the density anomaly of the wave boundary layer compared to the bottom-most sigma layer, the velocity of the overlying water, and the bathymetric slope. These velocities are used to estimate flux divergence within the wave boundary layer in the along- and across-shelf directions. Finally, changes to sediment concentration within the wave boundary layer are estimated by conserving sediment mass through horizontal and vertical advection, vertical diffusion, erosion, and deposition (for details, see Harris et al. [2004]).

\subsection{Erosion and Deposition}

[17] Both versions of the model calculate erosion and deposition using the net exchange between the seabed and the bottom-most layer overlying the sediment bed: either the bottom sigma layer (for conventional suspended transport), or the wave boundary layer (for fluid muds). Erosion and deposition are adjusted for $62 \%$ porosity, based on observations of flood beds [Wheatcroft and Borgeld, 2000]. Erosion during a time step is limited to the amount of sediment available at each grid cell. Because the model neglects sediment initially on the bed, any erosion therefore reworks sediment delivered by the flood.

\subsection{Representation of January 1997 Flood}

[18] The January 1997 flood is used to examine dispersal mechanisms and to compare observed and modeled depositional patterns. Calculations are first made assuming that all transport occurs as conventional suspended sediment transport. Then, the contribution of near-bed fluid mud layers is included using methods described in section 2.2. Freshwater from the Eel River enters as a point source. Winds and waves are assumed to be uniform, with the exception that heights are decreased in the few grid cells where waves would break. This simulation uses smoothed wind and discharge time series (see Figure 2), which simplifies boundary conditions, and also makes analysis of the results more straightforward compared to using the actual time series. Winds are strong and from the south during the beginning of the flood and then relax and turn to be from the north. These conditions are generally present during floods of the Eel River, based on analysis of available buoy and river gage data [Harris, 1999]. Wave heights of 3-m yield bed shear stress values similar to those seen during flood conditions on the Eel shelf. This representation of the flood serves as a baseline for comparison with other model runs, described next.

\subsection{Sensitivity Tests}

[19] We examine the sensitivity of depositional patterns to four parameters: flood magnitude, wave energy, settling velocity, and the bottom boundary condition.

[20] The settling velocities of fine-grained silts and clays that make up the midshelf mud bed can vary over several orders of magnitude in response to aggregation, disaggregation, and hindered settling processes. Settling velocity was usually assumed to be set at the river mouth [see Hill et al., 2000], neglecting disaggregation and aggregation on the continental shelf. On the basis of the work by Hill et al. [2000], $60 \%$ of the sediment was assumed to be packaged as flocculated particles, with a settling velocity of $w_{s}=$ $0.1 \mathrm{~cm} / \mathrm{s}$. The remaining $40 \%$ was assumed to travel as disaggregated, single particles $\left(w_{s}=0.01 \mathrm{~cm} / \mathrm{s}\right)$.

[21] For the fluid mud simulations, however, concentrations within the wave boundary layer grid cell often exceed 
Table 1. Flood Properties ${ }^{\mathrm{a}}$

\begin{tabular}{ccc}
\hline $\begin{array}{c}\text { Peak Freshwater } \\
\text { Discharge } Q, \mathrm{~m}^{3}\end{array}$ & $\begin{array}{c}\text { Peak Sediment } \\
\text { Concentration } C_{S}, \mathrm{~g} / \mathrm{L}\end{array}$ & $\begin{array}{c}\text { Total Load } \\
Q_{s}, \mathrm{~kg}\end{array}$ \\
\hline 3480 & 3.75 & $2.7 \times 10^{9}$ \\
5620 & 6.48 & $7.4 \times 10^{9}$ \\
7320 & 8.75 & $13.0 \times 10^{9}$ \\
9180 & 11.32 & $21.2 \times 10^{9}$ \\
\hline
\end{tabular}

${ }^{\mathrm{a}}$ Values follow rating curves from Syvitski and Morehead [1999] for floods for which they assign recurrence intervals of $2,5,10$, and 20 years, respectively.

$10 \mathrm{~g} / \mathrm{L}$ and as such could be subject to hindered settling [see Richardson and Zaki, 1954]. Estimates of hindered settling velocities vary widely and few, if any, of the relationships found in the literature were developed for energetic continental shelves. Some simulations included a concentrationdependent settling velocity in the wave boundary layer using relationships based on the work by Ross and Mehta [1989]. For these, settling velocities for $\sim 10-60 \mathrm{~g} / \mathrm{L}$ suspensions were reduced from $0.1 \mathrm{~cm} / \mathrm{s}$ to $0.07-0.002 \mathrm{~cm} / \mathrm{s}$.

[22] The most uncertain variable in the bottom boundary condition for sediment transport is the entrainment rate, and estimates of entrainment vary widely [see Garcia and Parker, 1991, 1993]. The sensitivity of calculations to this parameter was tested by doubling and halving the entrainment rates for both conventional and fluid mud formulations.

[23] Wave energy influences both the resuspension rate for conventional suspended transport and the thickness and sediment concentrations of fluid muds. The sensitivity of depositional patterns to waves was examined by using a range of wave heights, $H_{\text {sig }}=0-5 \mathrm{~m}$. Then temporal variability in wave heights was included by using the measured time series of wave energy (solid line in Figure 2c) for the 1997 flood.

[24] For fluid muds to dominate cross-shelf transport requires that sufficient sediment be available for suspension within the wave boundary layer. Flood magnitude directly impacts sediment supply. To evaluate the sediment load needed to trigger a near-bed gravity flow, calculations were run for a range of flood magnitudes. Sediment and freshwater discharges for each flood, provided in Table 1, were derived following rating curves of Syvitski and Morehead [1999]. Model behavior at the river mouth became unstable for very large floods (e.g., $\sim 21,000 \mathrm{~m}^{3} / \mathrm{s}$ ), precluding the simulation of more extreme events.

[25] Using these calculations, we test the hypothesis that combined transport from conventional suspension and nearbed fluid mud layers explain the formation of the midshelf mud bed, and investigate the short-term fate of sediment delivered to the continental shelf, including the $\sim 80 \%$ not trapped on the midshelf. Finally, we compare the relative contributions of dilute suspension to downslope transport of thin, turbid layers.

\section{Results}

[26] The structure predicted for plume and ocean currents is first described, followed by discussion of sediment transport. Three sets of calculations are included. The first uses idealized forcing to represent the 1997 Eel River flood, assuming sediment is transported only in dilute suspension. Calculations are then repeated, including the near-bed fluid mud layer. Finally, the sensitivity of depositional patterns to variations in model and environmental parameters is examined.

\subsection{Plume Structure and Ocean Currents}

[27] In both the model and observations by Geyer et al. [2000], the buoyant plume turned northward and hugged the coast under conditions of strong winds from the south and maximum flood discharge (Figures $3 \mathrm{a}$ and $3 \mathrm{~b}$ ). Within the model, the along-shelf component of momentum at the river mouth was increased to account for subgridscale effects of the orientation of the Eel River. The combination of river momentum, buoyancy, Coriolis, and wind forcing result in predictions of high velocities in the buoyant plume, up to $2 \mathrm{~m} / \mathrm{s}$, directed northward along the coast (Figure 4a). These are consistent with those observed by Geyer et al. [2000], who saw along-shelf velocities of nearly $0.5 \mathrm{~m} / \mathrm{s}$ during high discharges of the Eel River in 1998 and estimated plume velocities of $0.9-1.3 \mathrm{~m} / \mathrm{s}$ for the 1997 flood. In spite of downwelling favorable winds, predicted near-bed currents do not turn offshore but actually flow toward shore during the peak plume development (see Figure 4c). Plume structure, both modeled and observed, changes markedly when buoyancy input and winds relax between calendar days 3 and 6 (Figures 3c and 3d). By day 6, freshwater has spread to the midshelf and outer shelf (Figure 5a). Under these upwelling favorable, but relaxed winds, the model's buoyant plume is confined to surface waters, and water column velocities slow to a fraction of the speed attained under high winds. These calculations are also consistent with Geyer et al. [2000], in that both note a reversal of plume velocities during the second half of the flood in response to upwelling favorable winds.

\subsection{Suspended Sediment Dispersal}

[28] The modeled freshwater plume delivered sediment to the inner shelf both during the wind forced portion of the flood, and when wind velocities decreased (Figures 4 and 5, respectively), consistent with conclusions from Geyer et al. [2000]. During periods of strong northward winds, the buoyant plume is confined to the inner shelf and nearshore, because ocean currents are primarily directed along shore, even near the seabed (Figure 4). Suspended sediment settling from the plume under energetic winds is therefore subject to very little cross-shelf transport. As winds relax, the buoyant plume thins and spreads across the continental shelf (Figure 5a). While this carries a small amount of sediment across the shelf, most settles near the river mouth because plume velocities have slowed (Figure $5 \mathrm{c}$ ). Throughout the flood, therefore, the majority of sediment delivery to the bottom boundary layer is predicted to occur in shallow water within $\sim 15 \mathrm{~km}$ of the river mouth.

[29] Calculations show that dispersal patterns are extremely sensitive to the settling characteristics assumed for sediment. Unflocculated and flocculated sediment types follow very different transport paths. Flocculated sediment settles quickly and accounts for nearly all of the deposited material in Figure 5c. Much of unflocculated portion remains suspended, with some being transported north of Trinidad Head during the time of high winds. Unflocculated material is either transported out of the study area before winds reverse, or remains suspended throughout the simulation. It accounts for nearly all of the suspended sediment 

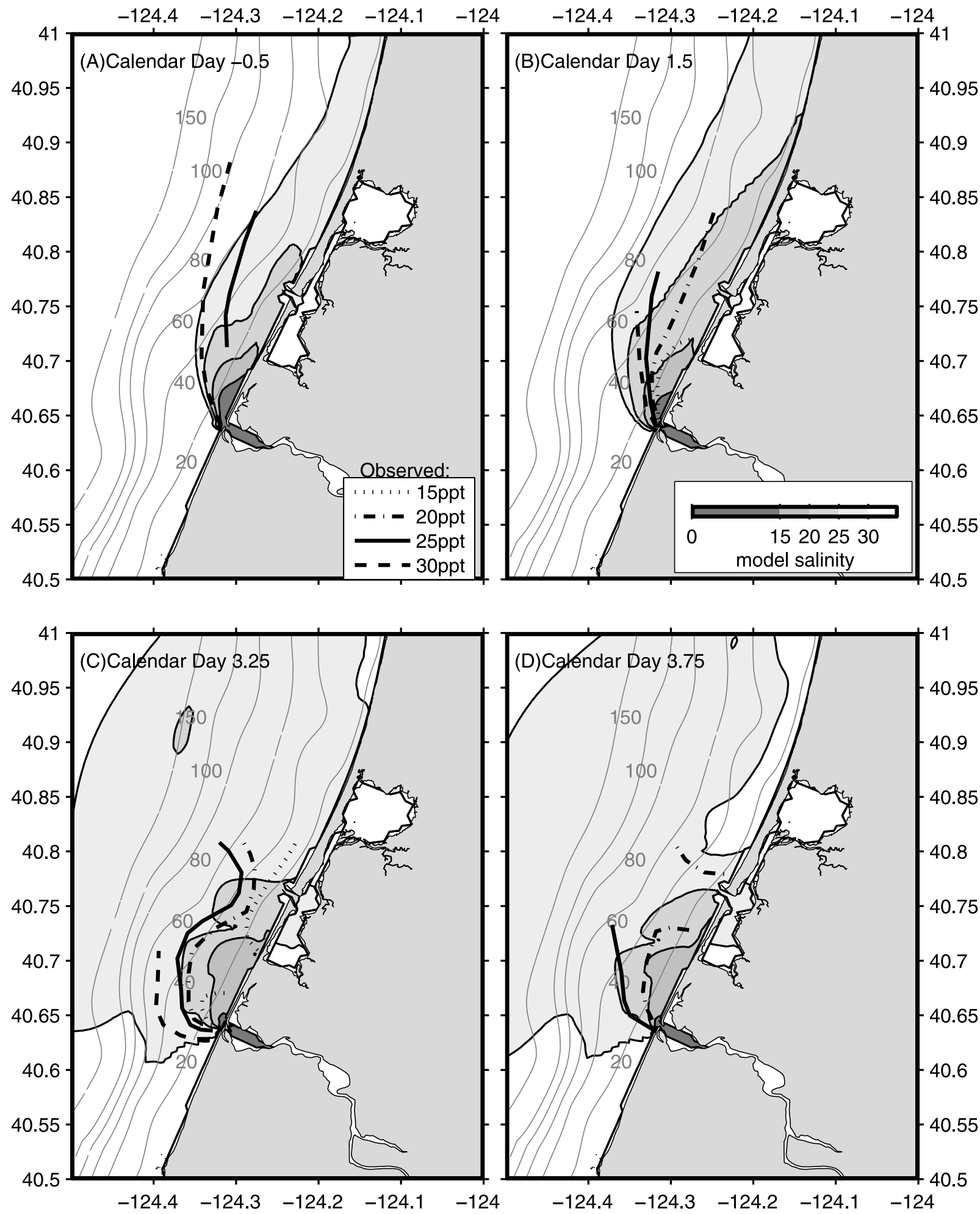

Figure 3. Freshwater plume predicted by model (see color bar) and observed by Geyer et al. [2000] (dark lines) for (a) 31 December 1996, (b) 2 January 1997, (c) morning of 3 January 1997, and (d) afternoon of 3 January 1997. Both modeled and observed contour lines are drawn at 15, 20, 25, and 30 ppt. Lighter lines are bathymetry. 
(a) Salinity

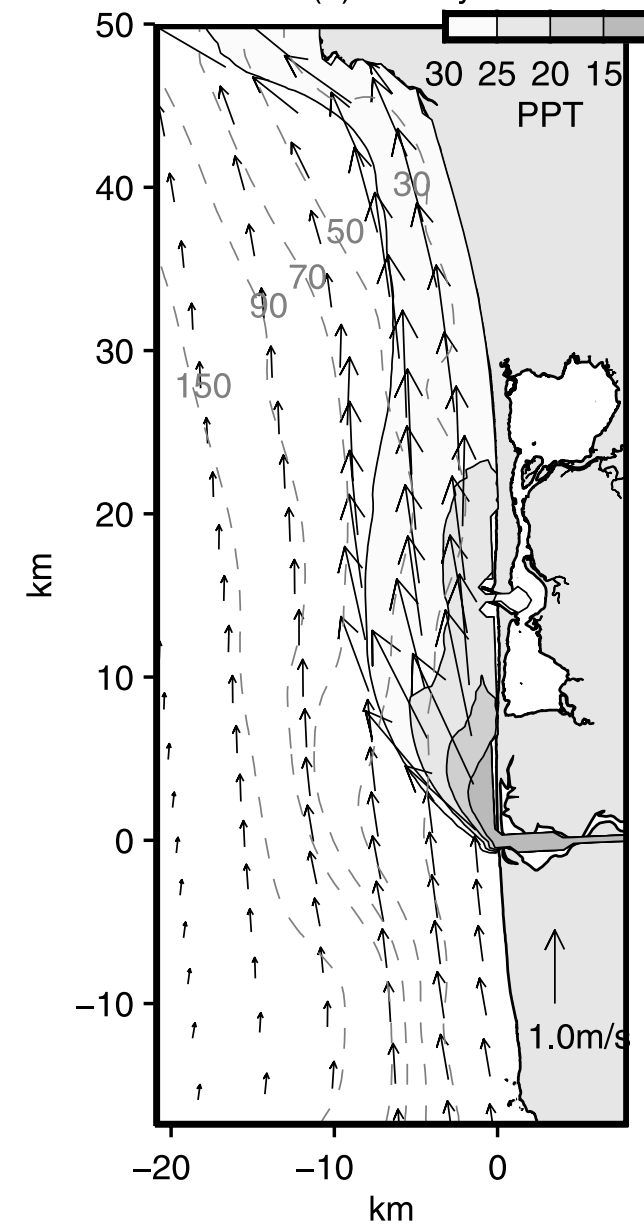

(b) Suspended Sediment

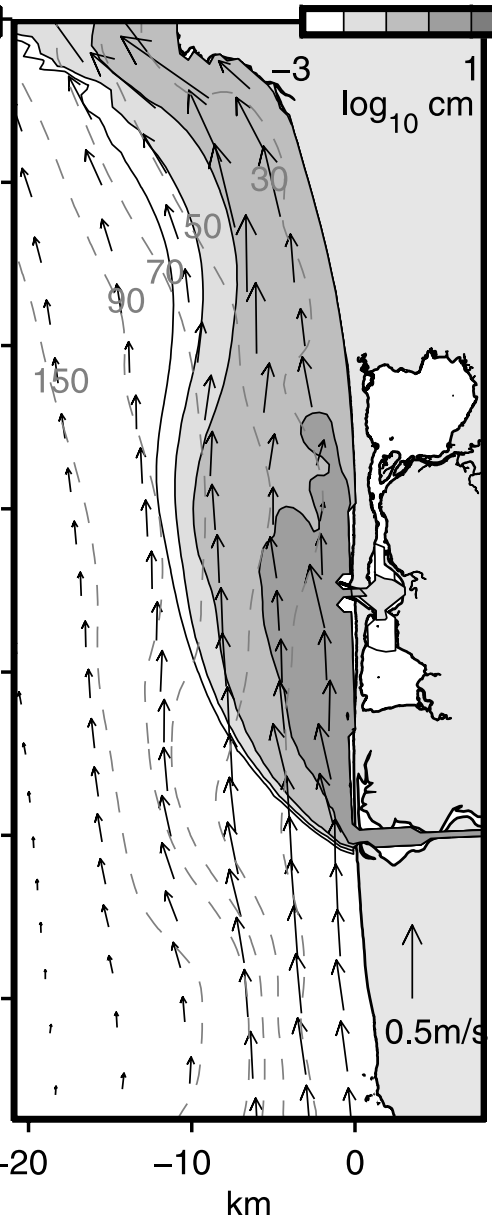

(c) Deposit

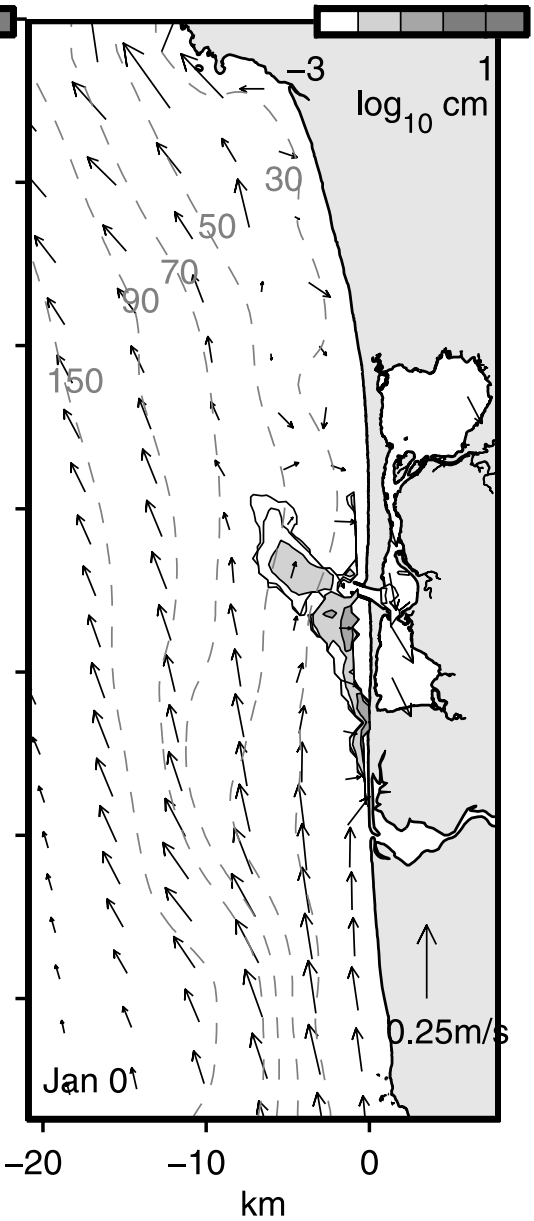

Figure 4. Calculations, neglecting near-bed turbid layer, of sediment dispersal and deposition at calendar day 0 (model day 3) during strong winds from the south. (a) Predicted salinity. (b) Depthintegrated suspended sediment representing the deposit thickness if all sediment settled to the bed. (c) Predicted deposition. Porosity of $62 \%$ is assumed in Figures $4 \mathrm{~b}$ and $4 \mathrm{c}$. Velocity arrows in Figure $4 \mathrm{a}$ represent velocity $1 \mathrm{~m}$ below sea surface, in Figure $4 \mathrm{~b}$ represent depth averages, and in Figure $4 \mathrm{c}$ represent velocity $1 \mathrm{~m}$ above bed (scales differ).

shown at calendar day 6 (Figure 5b), and all of the material exported.

[30] This model run transports a small amount of material to the mid shelf, but the volume of the predicted deposit is much smaller than what was observed following the 1997 flood by Sommerfield et al. [1999] and Wheatcroft and Borgeld [2000] (see Figure 5c). About the right volume of flocculated material was deposited, but its location on the inner shelf is inconsistent with the observations of midshelf muds made within a few weeks of floods. Other model runs with varying sediment settling rates, wave conditions, and tidal forcing, presented only briefly here, were unable to predict both the location and volume of midshelf deposition. Table 2 summarizes the sediment budgets for these, which included assuming all material to be flocculated or unflocculated. Model runs that used an intermediate value for settling velocity $\left(w_{s}=0.5 \mathrm{~cm} / \mathrm{s}\right)$ also failed to create a midshelf mud deposit. Other simulations included tides, a range of wave energies $\left(H_{\text {sig }}=0-5 \mathrm{~m}\right)$, and varied the entrainment rate by factors of 2 and 0.5 . None created a midshelf mud bed whose size and timing of formation matched observations on the Eel shelf. We therefore conclude that fluvial delivery and conventional suspended sediment transport does not create a midshelf mud deposit on the Eel River shelf within the time frame over which deposition has been observed to occur.

\subsection{Fluid Mud Dispersal}

[31] For direct comparison with section 3.2, this section describes calculations that include a near-bed turbid layer using the idealized forcing shown in Figure 2.

[32] Gravity driven transport, not significant early in the simulation, is initiated once the water column delivers sediment to the bottom boundary layer (Figure 6). By calendar day 1 (one day following peak sediment delivery), sediment supply in the inner shelf, combined with resuspension by energetic waves, creates a near-bed turbid layer whose offshore velocities overwhelm wind- and buoyancydriven currents (Figure 7b). During this time, transport within the near-bed turbid layer dominates cross-shelf flux (Figure 7c). This radically modifies the seabed predictions for calendar day 7, with deposition being dominated by 
(a) Salinity

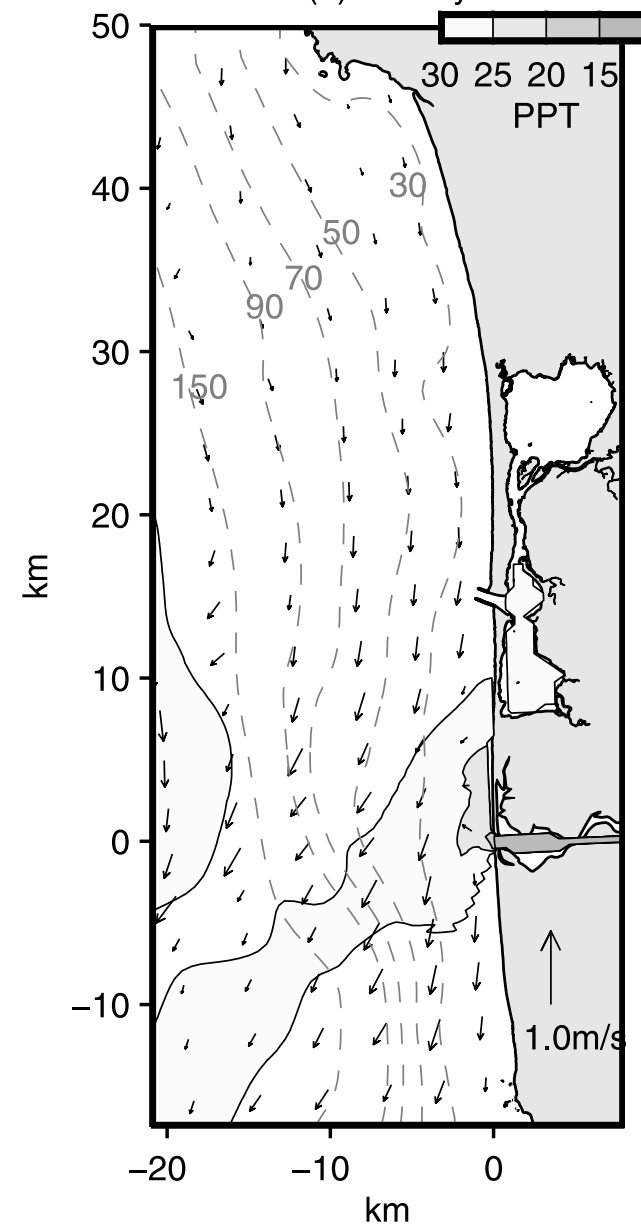

(b) Suspended Sediment

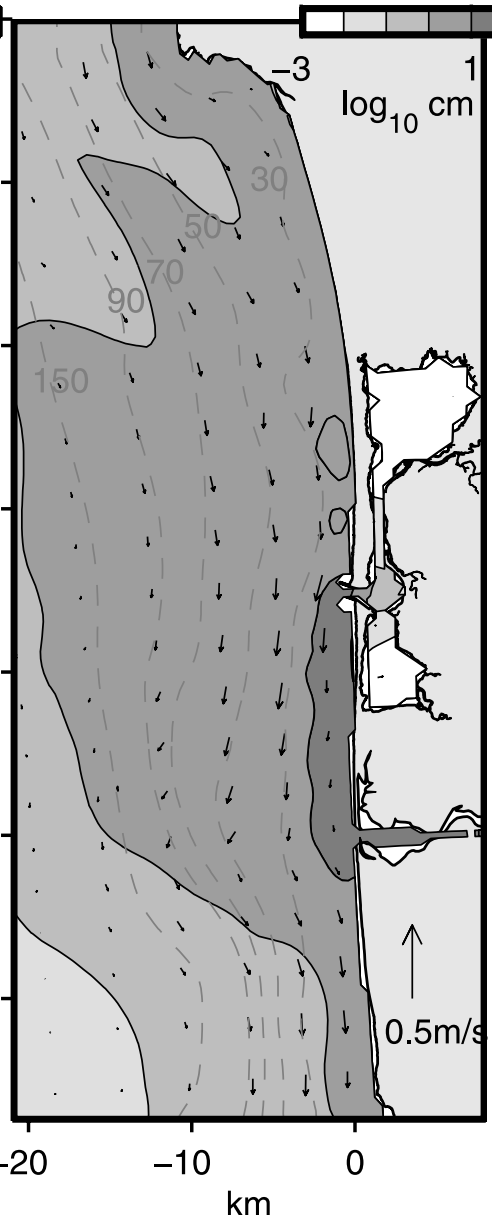

(c) Deposit

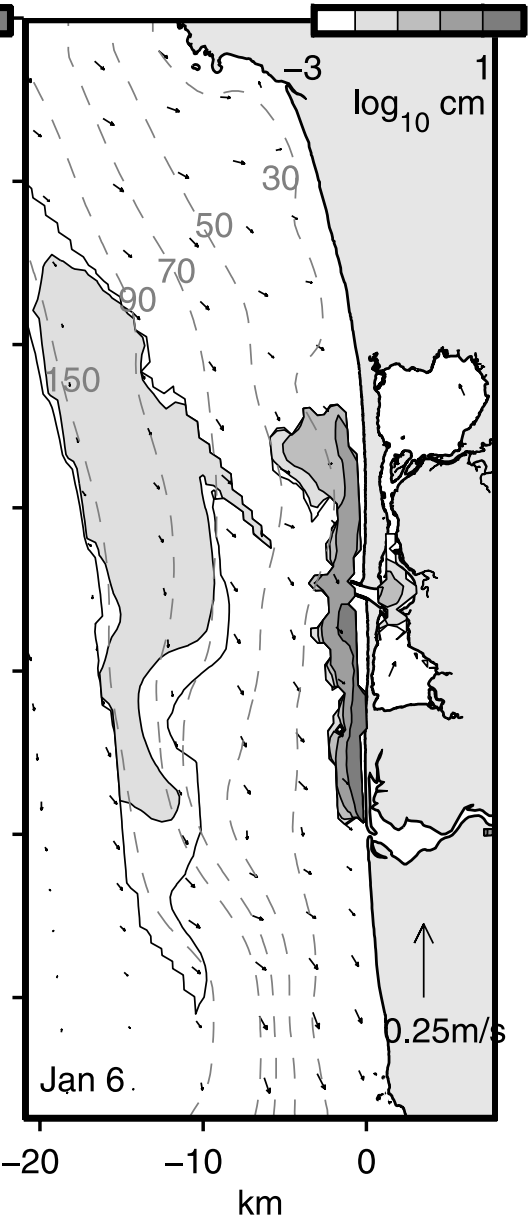

Figure 5. Calculations, neglecting near-bed turbid layer, of sediment dispersal and deposition at calendar day 6 (model day 9) during weak winds from the north. (a) Predicted salinity. (b) Depthintegrated suspended sediment representing the deposit thickness if all sediment settled to the bed. (c) Predicted deposition. Porosity of $62 \%$ assumed in Figures $5 \mathrm{~b}$ and 5c. Velocity arrows in Figure 5a represent velocity $1 \mathrm{~m}$ below sea surface, in Figure $5 \mathrm{~b}$ represent depth averages, and in Figure $5 \mathrm{c}$ represent velocity $1 \mathrm{~m}$ above bed (scales differ).

Table 2. Sediment Budgets for Calculations That Neglect Transport Within Near-Bed Turbid Layer ${ }^{\mathrm{a}}$

\begin{tabular}{|c|c|c|c|c|c|}
\hline \multirow[b]{2}{*}{ Forcing } & \multicolumn{2}{|c|}{$\begin{array}{c}\text { Sediment Remaining on } \\
\text { Shelf, \% }\end{array}$} & \multicolumn{3}{|c|}{ Sediment Transported off Shelf, \% } \\
\hline & $0-40 \mathrm{~m}$ & $40-200 \mathrm{~m}$ & To North & To Slope & To South \\
\hline Baseline $^{\mathrm{b}}$ & $58.9(38.4)$ & $15.3(0.7)$ & 21.9 & 1.6 & 1.6 \\
\hline With Tides ${ }^{c}$ & $65.0(43.9)$ & $10.1(1.3)$ & 23.6 & 0.8 & 0.0 \\
\hline Flocculated only, ${ }^{\mathrm{d}} w_{s}=0.1 \mathrm{~cm} / \mathrm{s}$ & $97.5(73.8)$ & $1.5(0.2)$ & 0.4 & 0.0 & 0.6 \\
\hline Unflocculated only, ${ }^{\mathrm{d}} w_{s}=0.01 \mathrm{~cm} / \mathrm{s}$ & $21.1(0.3)$ & $28.7(1.3)$ & 43.0 & 3.4 & 2.5 \\
\hline$H_{\text {sig }}=0 \mathrm{~m}^{\mathrm{e}}$ & $66.2(59.2)$ & $12.6(3.1)$ & 18.5 & 0.8 & 1.3 \\
\hline$H_{\mathrm{sig}}=5 \mathrm{~m}^{\mathrm{e}}$ & $66.6(39.4)$ & $12.8(0.4)$ & 17.2 & 1.4 & 1.5 \\
\hline Half erosion ${ }^{f}$ & $64.9(53.1)$ & $14.4(3.8)$ & 17.6 & 1.3 & 1.3 \\
\hline Double erosion $^{\mathrm{f}}$ & $66.9(44.4)$ & $12.4(0.7)$ & 17.4 & 1.4 & 1.4 \\
\hline
\end{tabular}

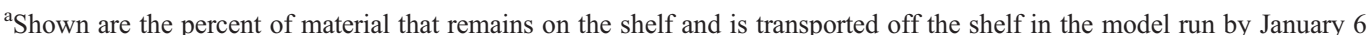
(model day 9). Sediment that remains is reported as either being on the nearshore to inner shelf $(0-40 \mathrm{~m})$, or on the midshelf to outer shelf $(40-200 \mathrm{~m})$, and includes both depth-integrated suspended and deposited sediment. Percentage of sediment load deposited shown in parentheses. Flux out of study area is divided into transport north of Trinidad Head, offshore of the 200-m isobath, or south of Cape Mendocino, and is estimated by time- and depth-integrating suspended sediment flux across each boundary.

${ }^{\mathrm{b}}$ The "baseline case" includes two sediment types and 3-m waves, but neglects tides.

${ }^{\mathrm{c}}$ Differ from baseline case by including tides.

${ }^{\mathrm{d}}$ Differ from baseline case by including only one sediment type.

${ }^{\mathrm{e}}$ Differ from baseline case by modifying wave energy.

${ }^{\mathrm{f}}$ Differ from baseline case by halving and doubling bed erosion rate. 
(A) Suspended

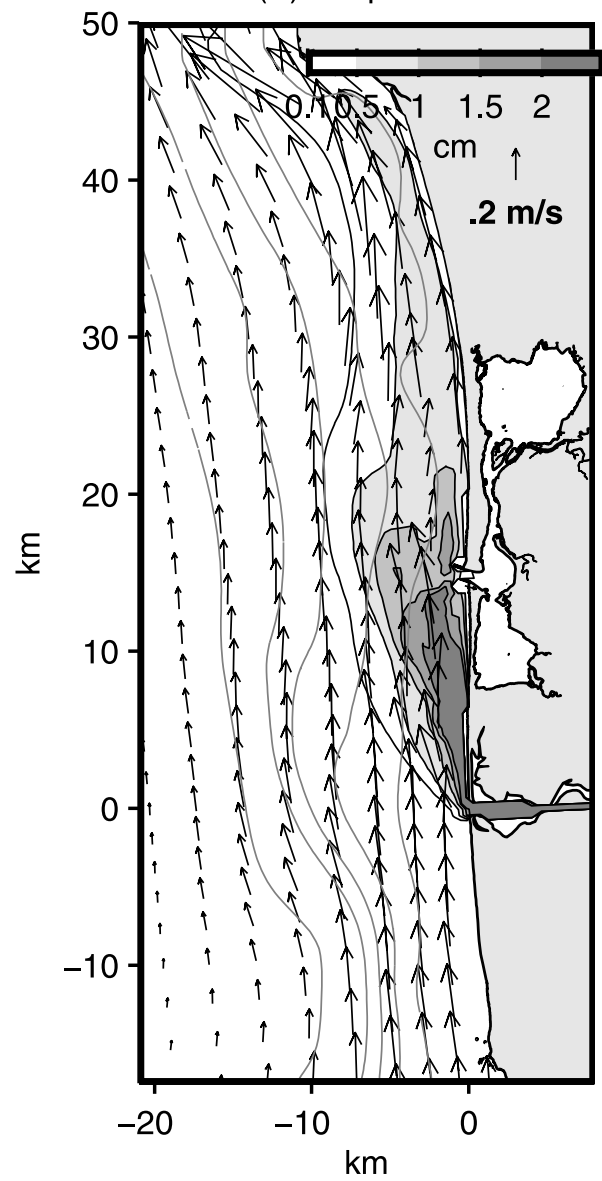

(B) In WBL

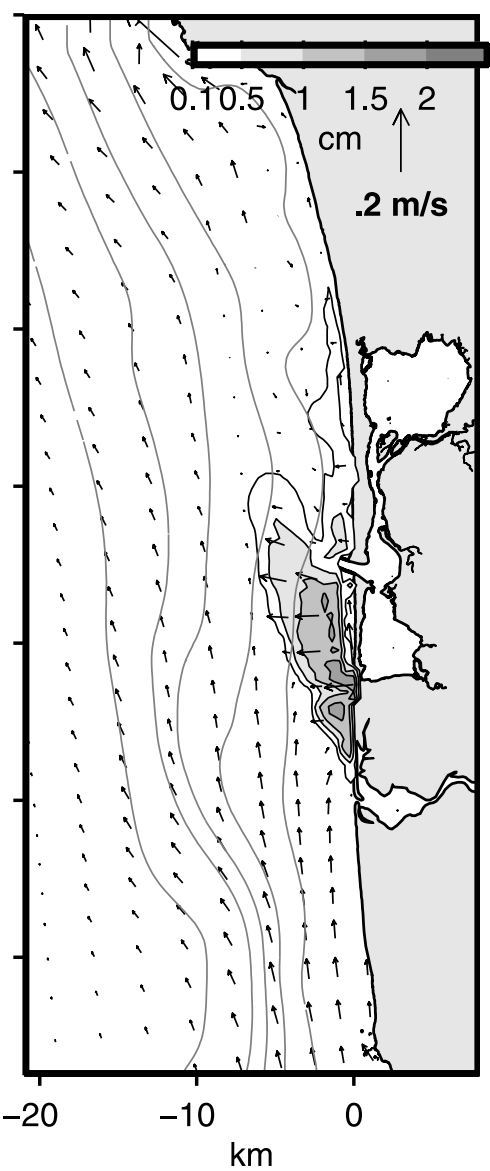

(C) Deposited

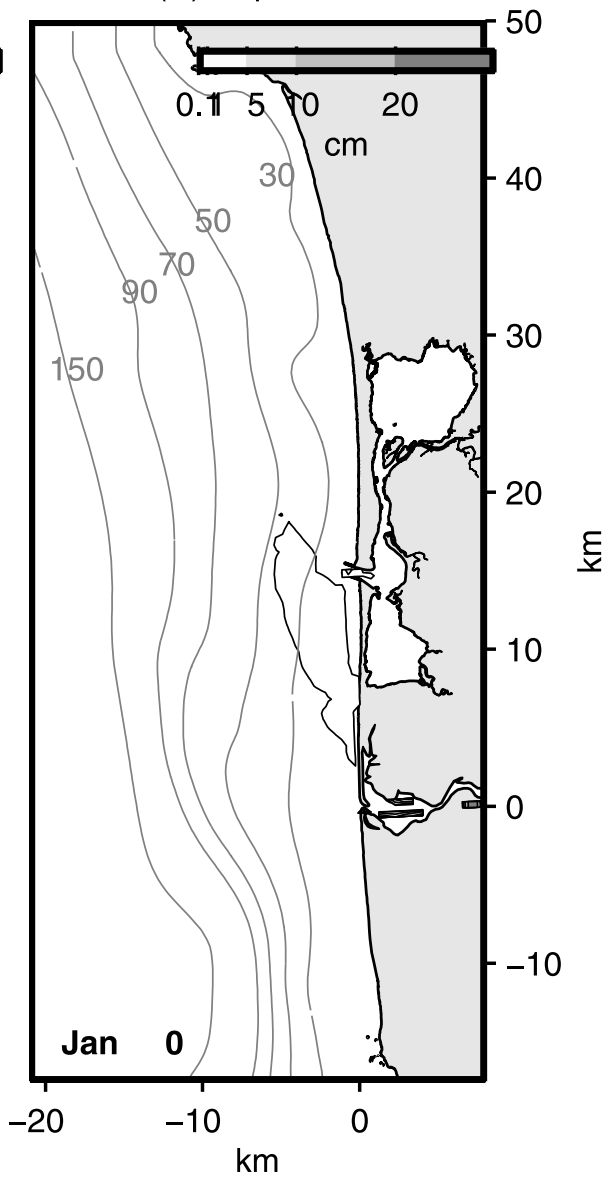

Figure 6. Calculations, including near-bed turbid layer, of sediment dispersal and deposition at calendar day 0 (model day 3). Equivalent depth (including porosity of $62 \%$ ) if all sediment in that layer settled to the bed is shown. (a) Amount suspended in the water column above the wave boundary layer. (b) Amount of sediment within the wave boundary layer. (c) Predicted deposition. Arrows in Figure 6a represent depth-averaged velocity of the water column and in Figure $6 \mathrm{~b}$ represent velocity of fluid mud layer. Note different scales used for velocities in Figures $6 \mathrm{a}$ and $6 \mathrm{~b}$.

a 5- to $10-\mathrm{cm}$-thick layer on the middle continental shelf (Figure 8c).

[33] Sediment budgets for the baseline calculation that includes transport of the thin near-bed fluid mud layer (Table 3) are consistent with those reported by Sommerfield and Nittrouer [1999] and Wheatcroft and Borgeld [2000]. About half of the unflocculated material is transported north of Trinidad Head, accounting for a loss of $\sim 20 \%$ of the input sediment. Most (99\%) of the flocculated material settles to the seafloor and remains on the Eel shelf. It is transported downslope to the middle continental shelf in the near-bed turbid layer. Once in deeper water, wave shear stress decreases, and turbulence generated by the waves can no longer maintain sediment in suspension. Within 10 days of the onset of flooding, this creates a mud bed that accounts for $\sim 30 \%$ of the input sediment.

[34] Velocities predicted within the wave boundary layer peaked at $\sim 0.18 \mathrm{~m} / \mathrm{s}$, slightly lower than the $0.20-0.35 \mathrm{~m} / \mathrm{s}$ off-shelf currents inferred for velocities within the wave boundary layer from measurements [Traykovski et al., 2000]. Sediment concentrations, based on acoustic backscatter (ABS) records were difficult to calibrate within the wave boundary layer, but exceeded $10-20 \mathrm{~g} / \mathrm{L}$ [Traykovski et al., 2000]. Modeled concentrations reached $200 \mathrm{~g} / \mathrm{L}$ but had a median value of $\sim 60 \mathrm{~g} / \mathrm{L}$ within the belt of fluid mud transport.

\subsection{Varying Wave Forcing}

[35] The previous calculations assumed steady and uniform waves $\left(H_{\mathrm{sig}}=3 \mathrm{~m}\right)$ to represent average conditions during the 1997 flood. To examine the sensitivity of the depositional signature to the magnitude and time history of wave forcing for the shelf, calculations were rerun using different wave heights $\left(H_{\text {sig }}=0-5 \mathrm{~m}\right)$, and then using measured wave heights for the 1997 flood (solid line in Figure 2c). These examples illustrate the influence of wave energy on the cross-shelf location of deposition, as demonstrated by Scully et al. [2003].

[36] The size of the midshelf mud deposit increased with increases in wave energy. Without waves $\left(H_{\text {sig }}=0\right)$, the gravity flow mechanism did not operate; wave shear stress was not present to resuspend sediment, so material settled quickly to the bed of the inner shelf (Table 3). Increasing wave heights from 3 to $5 \mathrm{~m}$ resulted in higher shear stresses 


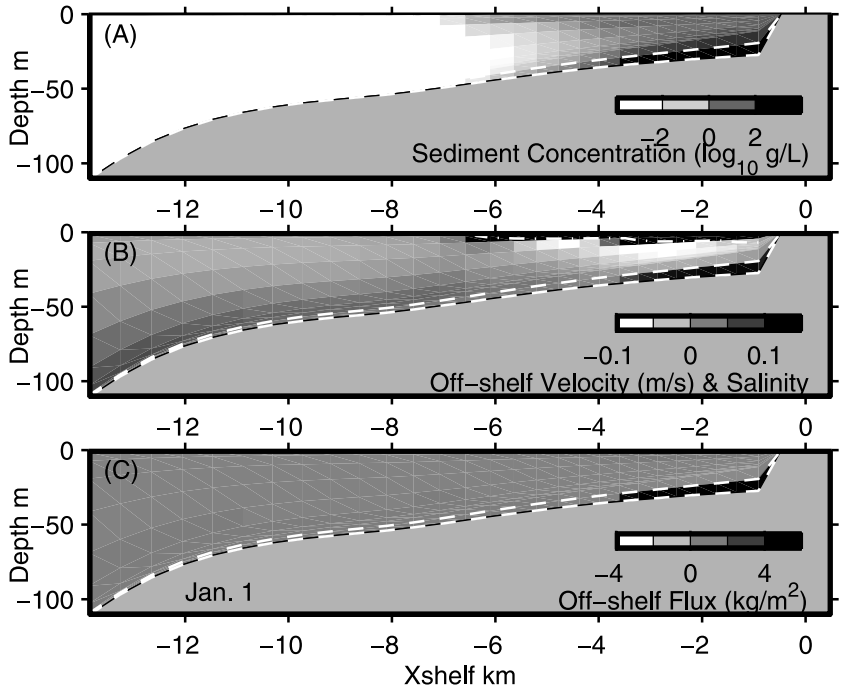

Figure 7. Across-shelf structure of water column and sediment dispersal at calendar day 1 in the simulation. Area beneath dashed line represent the near-bed fluid mud layer (vertical scale of this layer exaggerated by a factor of 40). (a) Sediment concentration. (b) Cross-shelf velocity. Dashdotted line at top represents contour line of $30 \mathrm{ppt}$ salinity. (c) Cross-shelf sediment flux.

capable of retaining slightly more sediment in suspension in the inner shelf. While the overall budget is similar (Table 3 ), the depositional footprint for 5-m waves is centered between 90 and $110 \mathrm{~m}$ water depth, $\sim 5 \mathrm{~km}$ offshore of that predicted for 3-m waves. Using the measured wave time series shifted the deposit toward shore compared to the steady, 3-m case (see Figure 9a), in response to the decrease in wave energy during the peak and waning phase of flood discharge (see Figure 2c).

\subsection{Sensitivity to Settling Velocity}

[37] Settling velocity impacts transport mechanisms and depositional patterns. Flocculated material $\left(w_{s}=0.1 \mathrm{~cm} / \mathrm{s}\right)$ settles from the freshwater plume within a few hours of delivery to the coastal ocean. Once sufficient sediment has been delivered to the near-bed region, it is mobilized within a thin turbid layer by energetic waves and transported to the midshelf within hours. Deposition occurs as the near-bed turbid layer reaches deeper water, where wave shear stress and the thickness of the wave boundary layer are reduced. This forms a thick deposit $(5-10 \mathrm{~cm})$ within days of sediment delivery to the ocean (see Figure 8a). Most of the unflocculated material $\left(w_{s}=0.01 \mathrm{~cm} / \mathrm{s}\right)$ remains suspended throughout the 10 day simulation, or is exported off the shelf to the north. It deposits a thin, widely dispersed drape of material.

[38] At high concentrations hindered settling occurs whereby interactions between sediment grains and the fluid act to slow settling of sediment [Richardson and Zaki, 1954]. Simulations were completed for the January 1997 flood that parameterized hindered settling in the wave boundary layer by including a concentration-dependent settling velocity following Marvan et al. [2002]. The lower settling velocities predicted using this relationship act to retain sediment in the wave boundary layer and transport it further offshore. The calculations made using the realistic time series of waves appear to be improved by inclusion of hindered settling compared to those made that assumed static settling velocities, because the depositional footprint (Figure 9b) better matches observations.

\section{Discussion}

[39] This section evaluates the sediment budget of a single storm event, and investigates the sensitivity of calculations to model processes and parameters.

\subsection{Sediment Budgets}

[40] The most realistic simulation of the January 1997 flood, in terms of forcing and the depositional footprint, uses smoothed bathymetry, a $60 \% / 40 \%$ partitioning of sediment within the flocculated and unflocculated classes, measured waves, and hindered settling (Figure 9b). The budget for this implies that $51 \%$ of the fine-grained sediment delivered to the coastal ocean would be retained on the midcontinental shelf for a week, with $30 \%$ being deposited (Table 3). Nearly all of the sediment deposited within this time entered the coastal ocean as flocculated material, most of which remains on the shelf. Unflocculated material is much more widely dispersed. Early in the simulation, strong winds from the south create fast currents that transport unflocculated material north of Trinidad Head. As winds relax, some of the unflocculated material is transported across the shelf within the thin surface plume (Figure $8 \mathrm{~b}$ ). This eventually settles to the sediment bed and accounts for a thin drape of sediment overlaying the thicker deposit of flocculated material.

[41] Most sediment exported from the Eel shelf during flood conditions exits to the north. A large fraction (20$30 \%$, Table 3 ) of the sediment delivered to the Eel shelf is estimated to be exported to the north of Trinidad Head as dilute suspended load. These materials may account for sediment from the Eel River watershed found on the Oregon and Washington continental shelves [Karlin, 1980]. Northward export is highest when winds are strong and from the south, and when the unflocculated fraction of the sediment load is high. Floc breakup in the near shore, as implied by Curran et al. [2002], would therefore increase this loss term. Because high winds from the south are typical during floods of the Eel River [Harris, 1999], northward export of sediment is likely a robust feature of flood dispersal.

[42] The smoothed bathymetry used in the model does not adequately represent the Eel Canyon (see Figure 1b), and therefore we can only imply general flux patterns to the canyon. Relatively little sediment is delivered to the south within the time frame of a flood, however (Table 3). As such, results indicate that postdelivery reworking is likely the source of the majority of sediment transported to the Eel Canyon.

\subsection{Relative Contributions of Transport Mechanisms}

[43] Whether dilute suspension dominates over near-bed gravity flows as a transport mechanism depends on several factors. First, to trigger a near-bed gravity flow, sufficient sediment must be available to raise concentrations within the wave boundary layer above $\sim 10 \mathrm{~g} / \mathrm{L}$. Second, waves must be energetic enough to suspend at least this amount of 
(A) Suspended

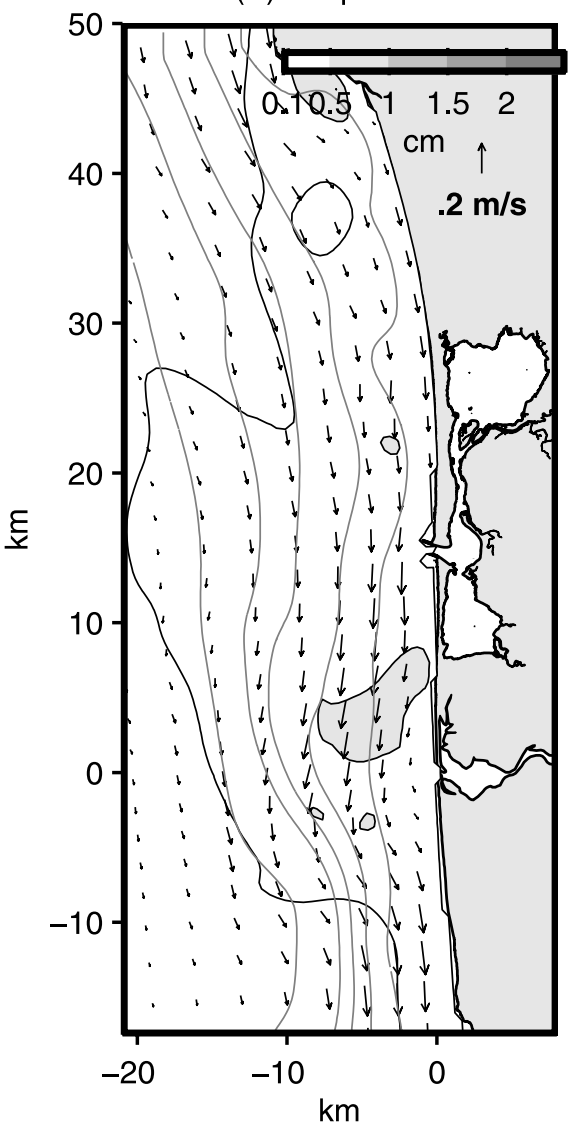

(B) In WBL

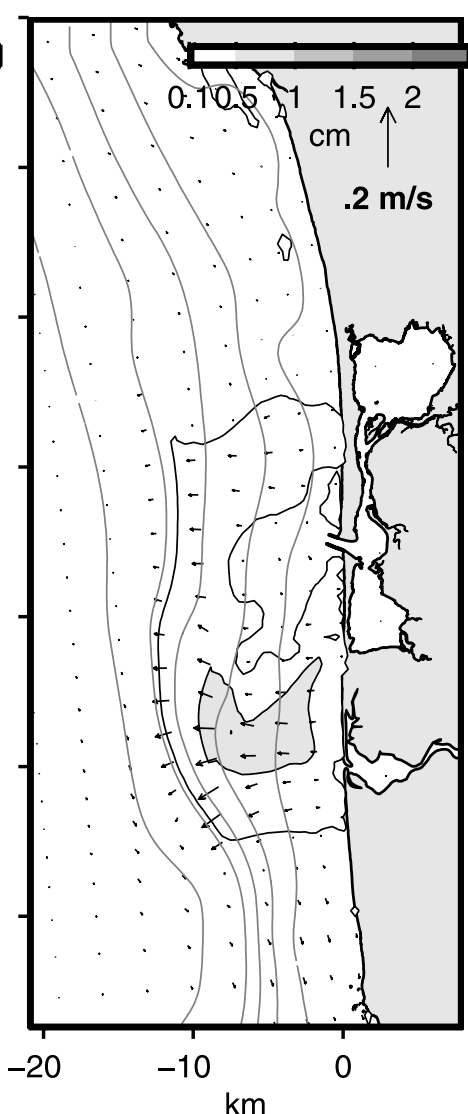

(C) Deposited

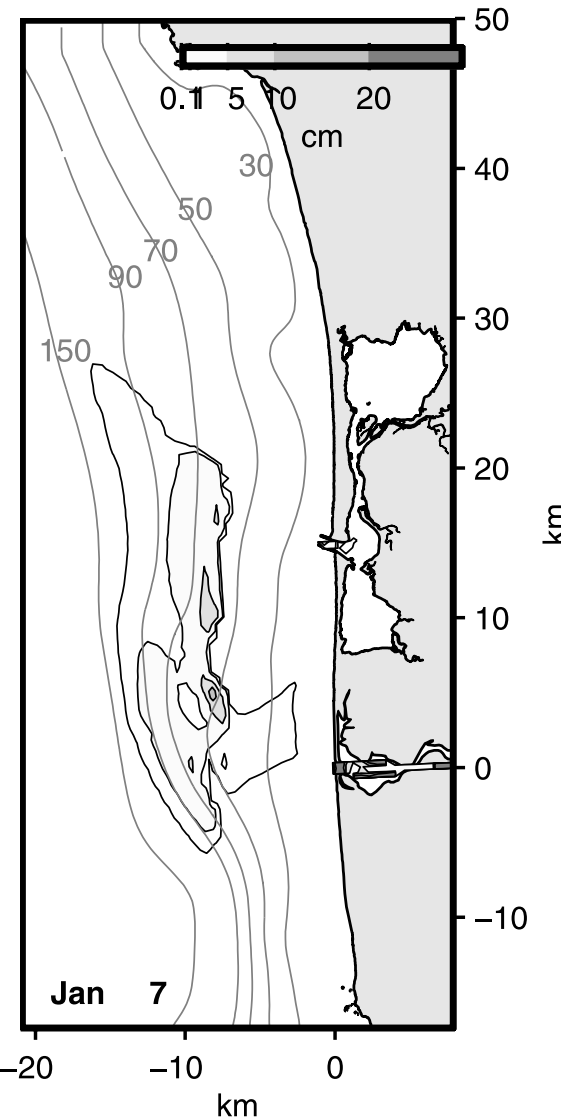

Figure 8. Calculations, including near-bed turbid layer, of sediment dispersal and deposition at calendar day 7 (model day 10). Equivalent depth (including porosity of 62\%) if all sediment in that layer settled to the bed is given. (a) Amount suspended in the water column above the wave boundary layer. (b) Amount of sediment within the wave boundary layer. (c) Predicted deposition. Arrows in Figure 8a represent depth-averaged velocity of the water column and in Figure $8 \mathrm{~b}$ represent velocity of fluid mud layer. Note different scales used for velocities in Figures $8 \mathrm{a}$ and $8 \mathrm{~b}$.

Table 3. Sediment Budgets for Model Runs That Included Gravity-Driven Transport Within Near-Bed Turbid Layer $^{\mathrm{a}}$

\begin{tabular}{|c|c|c|c|c|c|}
\hline \multirow[b]{2}{*}{ Forcing } & \multicolumn{2}{|c|}{$\begin{array}{c}\text { Sediment Remaining on } \\
\text { Shelf, \% }\end{array}$} & \multicolumn{3}{|c|}{ Sediment Transported off Shelf, \% } \\
\hline & $0-40 \mathrm{~m}$ & $40-200 \mathrm{~m}$ & To North & To Slope & To South \\
\hline Baseline $^{\mathrm{b}}$ & $20.7(1.5)$ & $52.6(30.7)$ & 23.5 & 1.4 & 1.6 \\
\hline Realistic Bathymetry $^{\mathrm{c}}$ & $39.0(7.8)$ & $23.3(2.4)$ & 33.0 & 1.0 & 3.0 \\
\hline Flocculated only: $w_{s}=0.1 \mathrm{~cm} / \mathrm{s}^{\mathrm{d}}$ & $22.0(2.7)$ & $77.0(60.2)$ & 0.6 & 0.0 & 0.6 \\
\hline Unflocculated only: $w_{s}=0.01 \mathrm{~cm} / \mathrm{s}^{\mathrm{d}}$ & $19.7(0.4)$ & $28.7(0.4)$ & 48.5 & 3.0 & 2.8 \\
\hline Half erosion ${ }^{\mathrm{e}}$ & $40.8(19.7)$ & $38.5(12.8)$ & 23.7 & 1.4 & 1.6 \\
\hline Double erosion ${ }^{\mathrm{e}}$ & $20.5(1.5)$ & $53.3(31.6)$ & 23.2 & 1.4 & 1.6 \\
\hline$H_{\text {sig }}=0 \mathrm{~m}^{\mathrm{f}}$ & $57.0(54.3)$ & $18.6(8.7)$ & 22.2 & 1.3 & 0.9 \\
\hline$H_{\text {sig }}=5 \mathrm{~m}^{\mathrm{f}}$ & $25.1(1.4)$ & $50.5(26.3)$ & 21.5 & 1.3 & 1.6 \\
\hline Actual waves ${ }^{\mathrm{f}}$ & $24.7(13.0)$ & $40.5(23.5)$ & 31.1 & 1.9 & 1.8 \\
\hline Hindered settling ${ }^{g}$ & $16.1(0.2)$ & $50.6(29.7)$ & 29.5 & -1.8 & -1.9 \\
\hline
\end{tabular}

${ }^{\text {aPercent }}$ of material that remains on the shelf and is transported off the shelf by January 6 (model day 9) is given. See Table 2 footnote.

${ }^{\mathrm{b}}$ The baseline case includes two sediment types and 3-m waves, uses smoothed bathymetry, and neglects tides.

${ }^{\mathrm{c}}$ Differ from baseline case by using realistic bathymetry.

${ }^{\mathrm{d}}$ Differ from baseline case by using only a single-sediment type.

${ }^{\mathrm{e}}$ Differ from baseline case by halving and doubling the bed erosion rate.

${ }^{\mathrm{f}}$ Differ from baseline case by modifying wave energy.

${ }^{g}$ Differ from baseline case by including hindered settling, using measured wave time series. 

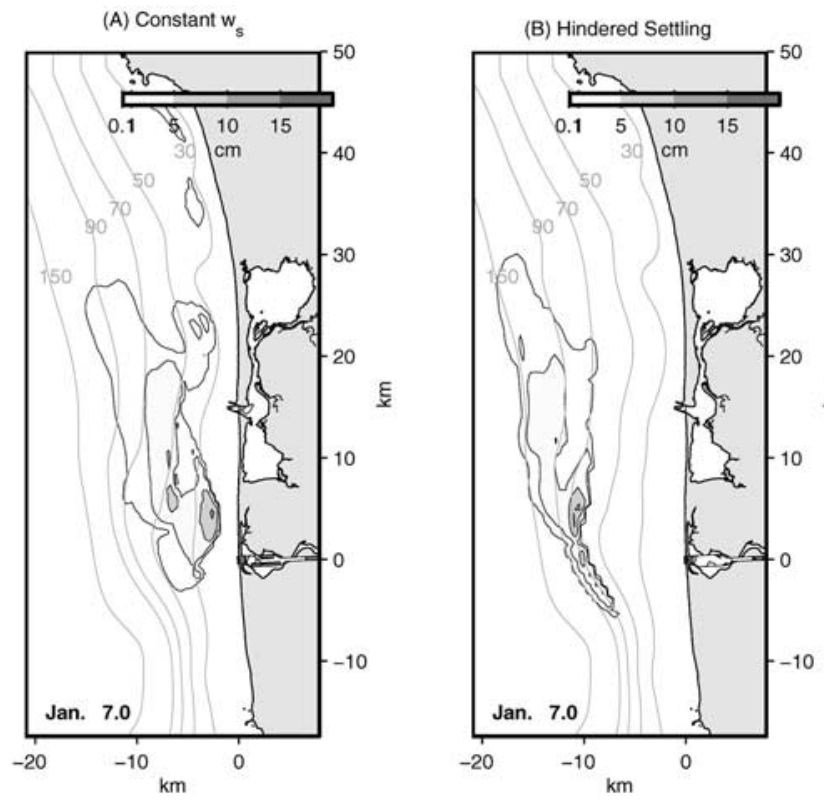

Figure 9. Sediment deposition at calendar day 7 (model day 10) using measured wave time series. Depth of deposit (including $62 \%$ porosity) is given. (a) Calculations made using prescribed settling velocity of $w_{s}=0.1$ or $0.01 \mathrm{~cm} / \mathrm{s}$. (b) Calculations made using hindered settling relationship described by Marvan et al. [2002].

sediment. The ability of a near-bed turbid layer to transport sediment therefore depends on wave properties, the magnitude of the flood, and associated sediment load. For a given set of flow conditions there should exist some threshold flood magnitude, under which near-bed gravity flows would be less important than dilute suspended transport. We tested this by calculating, for a range of sediment supplies and wave heights, the relative contributions of near-bed gravity flows and dilute transport to depth-integrated flux at a single point.

[44] Fluxes for the two mechanisms were evaluated at a location along the $30-\mathrm{m}$ isobath midway between the river mouth and Humboldt Bay (location shown in Figure 1). Depth integrated flux $(\mathrm{kg} / \mathrm{m} \mathrm{s})$ for the two layers was calculated as

$$
\begin{gathered}
Q_{s, \mathrm{wbl}}^{x}=\delta_{\mathrm{wbl}} c_{\mathrm{wbl}} U_{\mathrm{wbl}} ; \quad Q_{s, \mathrm{wbl}}^{y}=\delta_{\mathrm{wbl}} c_{\mathrm{wbl}} V_{\mathrm{wbl}} ; \\
Q_{s, S}^{x}=\int_{z=\delta_{\mathrm{wbl}}}^{h} c_{s} U d z ; \quad Q_{s, S}^{y}=\int_{z=\delta_{\mathrm{wbl}}}^{h} c_{S} V d z ;
\end{gathered}
$$

where $Q_{s, \text { wbl }}^{x}$ and $Q_{s, w b l}^{y}$ are sediment flux within the wave boundary layer in the across-shelf and along-shelf directions, respectively. $Q_{s, s}^{x}$, and $Q_{s, s}^{y}$ are the depth-integrated flux components of the overlying water. $U_{\text {wbl }}, V_{\text {wbl }}, U$, and $V$ are velocity components within the wave boundary layer and overlying water, respectively. These fluxes therefore include contributions from both along-shelf and across-shelf transport.

\subsubsection{Sensitivity to Supply}

[45] All but the smallest flood modeled (peak discharge $3480 \mathrm{~m}^{3} / \mathrm{s}$ ) supplied more sediment than could be carried by
Table 4. Sediment Budgets for Model Runs That Included Gravity-Driven Transport Within Near-Bed Turbid Layer for Floods Described in Table $1^{\text {a }}$

\begin{tabular}{ccccccc}
\hline & \multicolumn{2}{c}{$\begin{array}{c}\text { Sediment Remaining } \\
\text { on Shelf, } \%\end{array}$} & & \multicolumn{3}{c}{$\begin{array}{c}\text { Sediment Transported } \\
\text { Peak Flood }\end{array}$} \\
\cline { 2 - 3 } \cline { 5 - 7 } Discharge, $\mathrm{m}^{3} / \mathrm{s}$ & $0-40 \mathrm{~m}$ & $40-200 \mathrm{~m}$ & & To North & To Slope & To South \\
\hline 3480 & $40.0(2.1)$ & $27.2(0.1)$ & & 26.4 & 2.3 & 3.7 \\
5620 & $28.9(1.9)$ & $42.4(17.5)$ & & 24.9 & 1.5 & 2.1 \\
7320 & $20.9(1.2)$ & $52.8(29.9)$ & & 23.0 & 1.5 & 1.7 \\
9180 & $17.2(1.8)$ & $56.3(36.7)$ & & 23.5 & 1.5 & 1.4 \\
\hline
\end{tabular}

${ }^{\text {a }}$ Percent of material that remains on, and is transported off, the shelf by January 6 (model day 9) is shown. Fractions deposited are provided in parentheses. See Table 2 footnotes.

dilute suspension and showed evidence of near-bed gravity flow. The relative importance of water column versus wave boundary layer transport is evidenced both in the location of deposition and the sediment budgets calculated. As flood magnitude and sediment supply increase, more sediment is moved to, and retained on, the midshelf (Table 4).

[46] Cumulative plots of the along- and across-shelf flux calculated using equations (2) and (3) make interesting points (Figure 10). First, a threshold operates such that a critical amount of sediment must be supplied before gravitationally driven transport is triggered. For the waves,
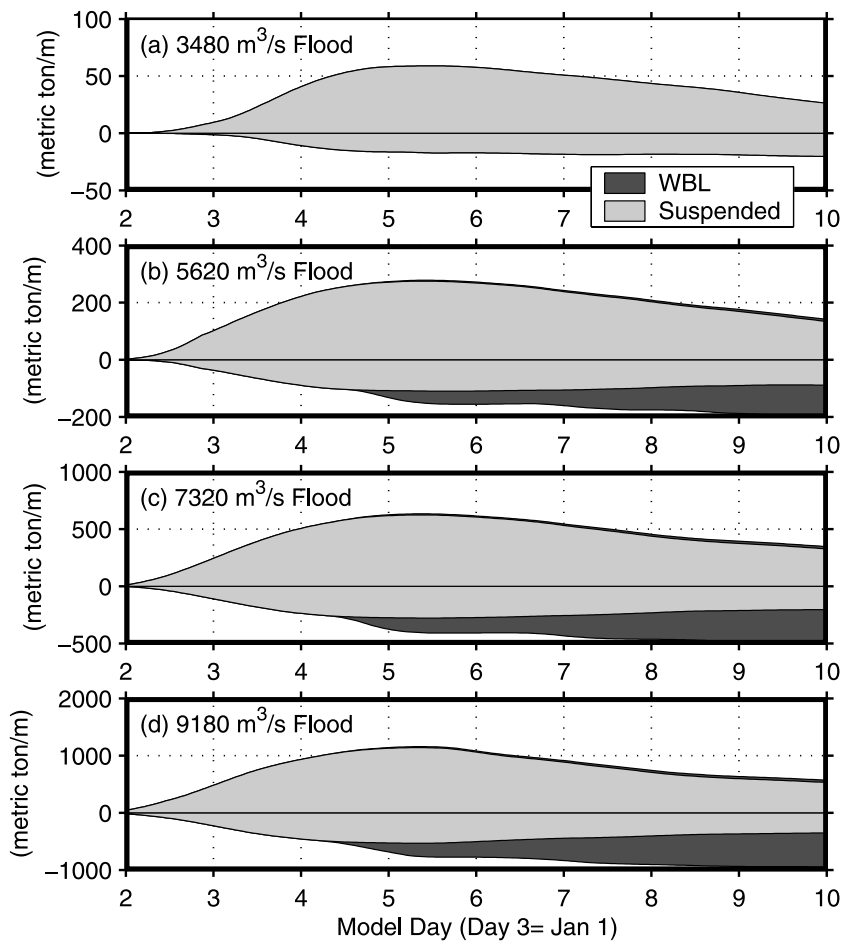

Figure 10. Cumulative flux estimated for total transport for the first 10 days of four simulated floods, each run with steady 3-m waves. Contributions from dilute suspended transport ("suspended") and gravitationally forced wave boundary layer transport ("WBL") are indicated by color. Positive values are along-shelf (northward) and negative values are cross-shelf (offshore) cumulative fluxes. Alongand across-shelf fluxes $(\mathrm{kg} / \mathrm{m})$ are calculated by time- and depth-integrating flux from each layer. Table 1 lists the freshwater and sediment discharges for these model runs. Figure 1 shows location of flux calculations. 

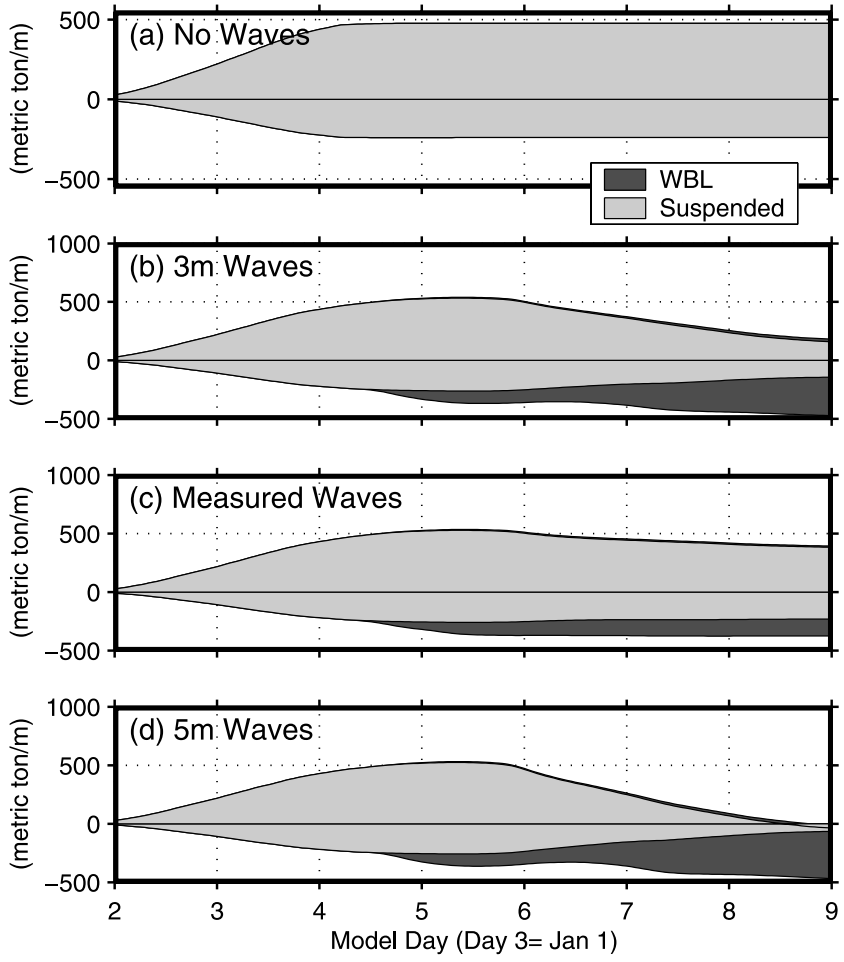

Figure 11. Cumulative flux estimated for total transport for the first 9 days of one flood run with four different wave conditions. Contributions from dilute suspended transport ("suspended") and gravitationally forced wave boundary layer transport ("WBL") are indicated by color. Positive values are along shelf (northward), and negative are crossshelf (offshore) cumulative fluxes. Along- and across-shelf fluxes $(\mathrm{kg} / \mathrm{m})$ are calculated by time- and depth-integrating flux from each layer. Figure 1 shows location of flux calculations.

currents, and bathymetric slope considered, the threshold appears intermediate between the floods that delivered sediment loads of $2.7 \times 10^{9}$ and $7.4 \times 10^{9} \mathrm{~kg}$ (Figures 10a and 10b). Second, gravitationally driven transport contributes strongly to across-shelf flux when it is present, accounting for about half of the total across-shelf flux for the floods that used 3-m waves (Figures $10 \mathrm{~b}-10 \mathrm{~d}$ ). Material transported as dilute suspension does, however, significantly supplement the total flux. This is consistent with observations by Traykovski et al. [2000] of $\sim 200 \mathrm{t} / \mathrm{m}$ transport in the alongshore and $100 \mathrm{t} / \mathrm{m}$ in the across shore; of which $80 \%$ was fluid mud.

[47] The temporal structure of the cumulative plots demonstrate that the timing of gravitational transport depends on supply of sediment to the near-bed region. In these simulations, waves are held constant. At this $30-\mathrm{m}$ site, dilute suspension dominates total transport during the first 4-5 days, even for the biggest floods (Figure 10). Gravitational transport begins one day past peak sediment delivery, when $80 \%$ of the sediment load has been supplied to the coastal ocean. At this time, enough sediment has been transported to this site to raise near-bed concentrations beyond the threshold needed for downslope transport. The timescale of 4.5 days for initiation of gravity flow therefore depends on the distance of the site from the river mouth, magnitude of along-shelf currents, and sediment settling velocity.

\subsubsection{Sensitivity to Wave Energy}

[48] The 1997 flood was rerun using a range of wave heights. Results indicate a threshold wave energy needed for gravitational transport, somewhere below $H_{\text {sig }}=3 \mathrm{~m}$, implying that near-bed gravity flows will impact sediment delivered by most floods of the Eel River, which usually occur during times of energetic waves [Harris, 1999]. Cumulative flux for the 30-m location midway between the Eel River mouth and Humboldt Bay (see Figure 1) indicates that the magnitude and relative dominance of gravitational flow is sensitive to wave energy (Figure 11). The dependency is not surprising, in that the vertical dimension of the fluid mud depends on the height of the wave boundary layer, and the concentration of sediment depends on wave shear stress. Increases in wave energy therefore increase wave boundary layer sediment load and, correspondingly, off-shelf velocities. For larger waves, the magnitude of the off-shelf-directed gravity flow increased and gained in importance compared to total flux (Figure 11). The dilute suspended load also responded to higher wave energies, particularly by being able to transport more sediment during the waning portion of the flood (Figure 11). In all wave-dominated cases, gravitational transport began around model day 4.5 , when near-bed sediment supply reached a critical level for the location analyzed.

[49] The case that used the measured wave time series (solid line in Figure 2c) demonstrates the sensitivity of gravitationally driven transport to instantaneous wave shear stress. The measured waves decrease after model day 3 , but gravitational transport is not initiated until a sufficient supply of sediment has reached the near bed region, at around model day 4.5. Gravitationally driven transport predicted using the measured waves is therefore much smaller than under a condition of average (3 m) waves (Figure 11).

\subsection{Uncertainties in Settling Velocity}

[50] Dispersal calculations are particularly sensitive to sediment settling characteristics. Tables 2 and 3 indicate that deposits formed by both suspended and fluid mud transport are radically modified when a reasonable range of settling velocities $\left(w_{s}=0.01-0.1 \mathrm{~cm} / \mathrm{s}\right)$ are considered. If the suspension is dominated by slowly settling, unflocculated particles, much of the load will be exported from the shelf. Only $4 \%$ of the unflocculated sediment settles to the bed within the 10 day period simulated. Conversely, if the flood sediment is dominated by fast settling, flocculated material, most of it will remain on the proximal shelf and will settle to the bed within hours to a few days of delivery to the coastal ocean.

[51] The input sediment distribution $(60 \%$ flocculated, and $40 \%$ unflocculated) was based on observations of sediment behavior within the flood plume. These concluded that the distribution of particles was determined in the Eel River, and not influenced by aggregation and disaggregation once discharged to the coastal ocean [Hill et al., 2000]. Uncertainties remain, however, in the degree to which finegrained sediments aggregate and disaggregate within turbulent, highly turbid layers. Studies made under lower concentrations have concluded that flocculated particles may be broken up by turbulence once they settle to the 
wave boundary layer [Hill et al., 2001]. Evidence from the Eel River shelf further indicates that floc formation and breakup in the nearshore may influence the size distribution of flocs [Curran et al., 2002], but these are neglected in our calculations. Floc breakup within the wave boundary layer could decrease settling velocities there. Disaggregation would also provide unflocculated material that could be mixed upward out of the wave boundary layer and then be widely dispersed in dilute suspension.

[52] Interactions between suspended sediment grains and the fluid slow settling when concentrations exceed $\sim 10 \mathrm{~g} / \mathrm{L}$ [Richardson and Zaki, 1954]. The degree to which such hindered settling processes influence depositional signatures from near-bed gravity flows is poorly constrained, because there is no consensus for predicting settling rates of fluid muds [see Ross and Mehta, 1989; Toorman, 1998; Winterwerp, 2002]. Decreased settling velocities should delay deposition of sediment from the wave boundary layer and shift deposition to deeper water by increasing both concentrations in the wave boundary layer and cross-shelf velocities. Use of a hindered settling term appears to improve the model's predictive skill by increasing transport to the midshelf (Figure 9b) and creating a midshelf flood deposit using the measured time series of waves as input.

[53] Specifying the settling properties of fine-grained sediment remains difficult in continental shelf environments. Between the river mouth and midshelf mud bed, sediment is subject to a range of concentration, turbulence, and salinity regimes. Both aggregation and hindered settling relationships are poorly constrained for these conditions. Ongoing efforts aimed at obtaining in situ measurements of settling velocities are therefore critical to developing predictive models of sediment dispersal and deposition for continental shelves.

\subsection{Uncertainties in Sediment Budgets}

[54] The ability to use field observations to derive sediment budgets depends on the accuracy with which sediment load can be quantified for any particular flood. Sediment rating curves for the Eel River show an order of magnitude of scatter for any particular discharge [Wheatcroft et al., 1997; Syvitski and Morehead, 1999; Geyer et al., 2000]. Uncertainty is confounded for extremely large floods, for which Wheatcroft et al. [1997] argue for a cap of $10 \mathrm{~g} / \mathrm{L}$ for sediment concentrations, while Syvitski and Morehead [1999] predict average loads in excess of $20 \mathrm{~g} / \mathrm{L}$. Doubling sediment input more than doubles our predictions of deposition, because the formulation for sediment entrainment (equation (1)) allows the flow to disperse a fairly constant sediment load, based on $C_{\text {ref. }}$.

[55] Extrapolating our results to longer timescales is problematic. Large floods are likely to influence sediment budgets, but may react to transport mechanisms that this model neglects. For floods whose concentrations exceed $\sim 40 \mathrm{~g} / \mathrm{L}$ hyperpycnal flows could issue from the river mouth, by which sediment-laden freshwater plunges upon reaching the coastal ocean [Mulder and Syvitski, 1995]. The largest historical floods of the Eel River have been interpreted as producing these [Syvitski and Morehead, 1999]. The model presented here does not treat river-initiated hyperpycnal flows, and became unstable when simulations of large floods were attempted. We therefore cannot spec- ulate on the depositional and dispersal signatures likely to be created by hyperpycnal floods.

[56] Another difficulty in comparing predicted sediment budgets to observations lies in the model's inability to represent postflood reworking. Sediment cores of the 1997 flood were taken a few weeks after the flood, during which times waves were fairly energetic [Harris, 1999]. Observations from tripods on the Eel River shelf show that up to one half of observed flood thickness was removed within a timescale of a few weeks by wave resuspension [Traykovski et al., 2000]. These are not resolved by the present model because it simulates less than a week past peak flood conditions. Continued reworking of the midshelf mud bed during the two weeks after the flood may partially explain the discrepancy between our predicted mass of the mud deposit ( $\sim 30 \%)$ and the observed value of $\sim 20 \%$ [Sommerfield et al., 1999; Wheatcroft and Borgeld, 2000].

\subsection{Interaction Between Shelf and Fluvial Sediment}

[57] This numerical model neglects shelf sediment not delivered by the flood. While it predicts that a substantial part of the fine sediment load (nearly 60\%) has the opportunity to interact with inner shelf sands, it cannot evaluate the outcome of this interaction. Shelf sands can impact dispersal of flood sediment in two ways. They provide a source of material that would increase sediment concentrations (and thus velocities) within the wave boundary layer and possibly trigger gravitational transport earlier in the flood, and for smaller floods. A more significant effect, perhaps, is the ability of mobile sands to incorporate flood sediment within the matrix of the sediment bed as noted by Crockett and Nittrouer [2004]. Once sequestered within the layer of actively transported sand, these fine grained materials might remain buried on the inner shelf, or possibly be resuspended under later, stormy, nonflood periods. Interaction with shelf sands could be particularly important to postflood reworking, when transport is primarily driven by resuspension instead of plume delivery. Drake [1999] shows that a substantial amount of shelf silts and fine sands are added to flood-derived muds on the midshelf within timescales of a few years after a flood deposit is formed. Accounting for these processes would require longer simulations, and a model that includes multiple grain sizes and accounts for small-scale size gradations in the seabed [e.g., Harris and Wiberg, 2001, 2002].

[58] Instabilities that appeared on the boundaries after $\sim 10-14$ days of simulated time precluded long model runs that included postdepositional reworking. For this reason, the present model cannot evaluate how large a flood is needed to create a preservable flood deposit. For example, this model would predict the formation of a midshelf mud bed by flood pulses observed during the winter of 1998 . Observations indicate, however, that these initial deposits were reworked and destroyed by subsequent wavedominated resuspension. Solving the open boundary problem for models of plume-dominated shelf environments and incorporating models of seabed stratigraphy into threedimensional models hold promise for extending these predictions beyond the timescale of a single flood.

\subsection{Shelf Circulation}

[59] Another possible explanation for the location of the midshelf mud bed is focusing of sediment flux by conver- 
gence of large-scale ocean currents. Such features have been identified as potentially important offshore of the Eel River. Hydrodynamic models by Pullen and Allen [2000, 2001] identify an anticyclonic eddy that appears to be centered near the midshelf mud bed. Wright et al. [1999] observed convergent near-bed current velocities between the 60 - and $70-\mathrm{m}$ isobaths of the Eel shelf. This level of convergence in ocean currents can significantly reinforce mud deposition on the midshelf [Harris, 1999]. It is unlikely, however, that such features explain the formation of the mud bed. The majority of newly delivered mud settles to the bottom boundary layer inshore of the $30-\mathrm{m}$ isobath, as predicted here and seen by Geyer et al. [2000]. As such, flood layer formation would not be strongly impacted by water column currents. The degree to which flux convergence helps maintain a flood bed once deposited could be addressed through another study that includes sediment transport within a model using nested boundary conditions capable of resolving the large-scale circulation features, such as used by Pullen and Allen [2000, 2001].

\subsection{Controls on Along-Shelf Deposition}

[60] Bed slope, settling velocity, and plume trajectory influence the along-shelf location of deposition. Both the along-shelf and cross-shelf components of slope impact the formulation for fluid mud velocity. The effect of along-shelf slope is illustrated by the trajectories of the wave boundary layer sediment in Figure $8 \mathrm{~b}$, where sediment is steered downslope toward the midshelf depocenter. Scully et al. [2003] conclude that along-shelf slope increases deposition in the midshelf region $10-30 \mathrm{~km}$ north of the river mouth by $39 \%$. In this way, flood deposition reinforces long-term depositional trends. Along-shelf distribution is also influenced by the direction and magnitude of plume currents and sediment settling velocity. At flood peak, sediment is transported northward at high speeds and predicted to settle on the inner shelf within $0-20 \mathrm{~km}$ north of the river mouth (Figure 6). Because winds tend to be strong and from the south during floods, this trajectory is likely the normal route for Eel River flood plumes. Uncertainties in settling velocity of flood material could spread or compress the deposit. For example, disaggregation of flood material in the nearshore could act to elongate the along-shelf location of the flood deposit, and move it toward the north.

\subsection{Transport Pathways and Implications}

[61] The two modeled sediment classes respond to different transport mechanisms. Flocculated material settles to the seabed within a few hours of delivery to the coastal ocean. Conversely, unflocculated material requires days to weeks to settle to the bed, and is more widely dispersed within oceanic waters. Terrestrial material packaged as aggregates is more likely to be rapidly buried in the marine environment than material within the unflocculated fraction. The length of time that unflocculated material spends as suspended load implies that it would be more subject to sorting mechanisms based on the hydrodynamic properties of sediment grains, than would the flocculated material that is primarily delivered via gravity flows. Besides size gradation, sediment traveling within these two transport modes would be exposed to oceanic conditions for different timescales; hours for material within the near-bed turbid plume, compared to days for dispersed material. This could have implications for geochemical interactions between the sediment, organic matter or contaminants associated with the sediment, and seawater.

\section{Conclusions}

[62] Calculations that include freshwater plume delivery of sediment, suspended load, and cross-shelf transport within a thin near-bed turbid layer match the dispersal and depositional patterns observed for the January 1997 flood of the Eel River. Calculations that neglect gravitationally driven transport do not create a midshelf mud bed of the size observed, and deposit sediment on the midshelf more slowly than observations would indicate. Dispersal patterns are most sensitive to sediment settling characteristics. Accurate representations of settling velocities within highly turbid layers are therefore key to predicting sedimentation and dispersal in coastal areas impacted by fluvial delivery of sediment.

[63] Dilute suspension dominates the transport path of the unflocculated portion of the sediment load, which follows ambient currents. Strong wind-driven currents export unflocculated sediment northward from the Eel shelf. Dilute suspended load does not create a distinct midshelf deposit but rather builds a thin and widely dispersed drape of material. It therefore does not explain depositional patterns observed on the Eel River shelf. Dispersal by dilute suspension is, however, important in determining the overall sediment budget, and accounts for a large portion of the sediment that leaves the Eel shelf.

[64] Flocculated material settles from the fluvial plume within a few kilometers of the river mouth, and is delivered to the near-bed region very quickly. On the Eel River shelf, intense waves act to suspend this material within the thin wave boundary layer, and gravitational forcing of the turbid layer creates a cross-shelf mechanism for downslope transport. Deposition of this material depends on the relative settling rates of sediment within the turbid layer and the waves' ability to resuspend sediment. Because wave shear stress decreases with increasing water depth, sediment deposition occurs at midcontinental shelf depths. For the system considered here, the deposition can create flood deposits on the order of 5-10 cm thick, consistent with observations from the STRATAFORM program.

[65] The sensitivity of dispersion and deposition of finegrained sediment to settling properties is demonstrated by sediment budgets calculated for flocculated and unflocculated material. The settling properties of the fluid mud also impact the depositional signature, with hindered settling increasing cross-shelf transport by a few kilometers. A better understanding of sediment aggregation, disaggregation, and hindered settling, both within the plume and within the wave boundary layer is needed. Also, consideration of how newly delivered fines interact with sands and silts already resident on the continental shelf is necessary to understand postdepositional reworking of shelf sediments and sequestering of muds on the inner shelf.

[66] Acknowledgments. The Office of Naval Research's Coastal Geoscience Program supported this through program N0014-01-1-008. Efforts in guiding STRATAFORM, particularly by Joe Kravitz and Chuck Nittrouer, are appreciated. The authors also are grateful for input from Rich Signell (U.S. Geological Survey) during early development of the model. 
Suggestions from Tara Kniskern, Malcolm Scully (both at VIMS), and two anonymous reviewers improved the manuscript. This is contribution 2679 of the Virginia Institute of Marine Science.

\section{References}

Blumberg, A. F., and G. L. Mellor (1987), A description of a three-dimensional coastal ocean circulation model, in Three-Dimensional Coastal Ocean Models, Coastal Estuarine Sci., vol. 4, edited by N. S. Heaps, pp. 1-16, AGU, Washington, D. C.

Cacchione, D. A., P. L. Wiberg, J. F. Lynch, J. D. Irish, and P. A Traykovski (1999), Estimates of suspended-sediment flux and bedform activity on the inner portion of Eel River continental shelf, Mar. Geol., 154, 83-97.

Crockett, J., and C. A. Nittrouer (2004), The sandy inner shelf as a repository for muddy sediment: An example from northern California, Cont. Shelf Res., 24, 55-73.

Curran, K., P. Hill, and T. Milligan (2002), Fine grained suspended sediment dynamics in the Eel River flood plume, Cont. Shelf Res., 22, $2537-$ 2550 .

Drake, D. E. (1999), Temporal and spatial variability of the sediment grainsize distribution of the Eel shelf: The flood layer of 1995, Mar. Geol., $154,169-182$.

Fan, S., D. J. P. Swift, P. A. Traykovski, S. J. Bentley, J. C. Borgeld, C. W. Reed, and A. W. Niedoroda (2004), River flooding, storm resuspension, and event stratigraphy on the northern California shelf: Observations compared with simulations, Mar. Geol., 210, 17-41.

Field, M. E., J. J. H. Barber, D. A. Cacchione, D. E. Drake, and F. L. Wong (1992), Holocene sediment map of the central California continental shelf, technical report, U.S. Geol. Surv., Denver, Colo.

Garcia, M. H., and G. Parker (1991), Entrainment of bed sediment into suspension, J. Hydraul. Eng., 117(4), 414-435.

Garcia, M. H., and G. Parker (1993), Experiments on the entrainment of sediment into suspension by a dense bottom current, J. Geophys. Res., 98, $4793-4807$

Geyer, W. R., P. S. Hill, T. G. Milligan, and P. A. Traykovski (2000), The structure of the Eel River plume during floods, Cont. Shelf Res., 20, 2095-2111.

Griggs, G. B., and J. R. Hein (1980), Sources, dispersal, and clay mineral composition of fine-grained sediment off central and northern California, J. Geol., 88, 541-566.

Harris, C. K. (1999), The importance of advection and flux divergence in the transport and redistribution of continental shelf sediment, Ph.D. thesis, Univ. of Va., Charlottesville.

Harris, C. K., and P. L. Wiberg (2001), A two-dimensional, time-dependent model of suspended sediment transport and bed reworking for continental shelves, Comput. Geosci., 27(6), 675-690.

Harris, C. K., and P. Wiberg (2002), Across-shelf sediment transport: Interactions between suspended sediment and bed sediment, J. Geophys. Res., 107(C1), 3008, doi:10.1029/2000JC000634.

Harris, C. K., P. A. Traykovski, and W. R. Geyer (2004), Including a nearbed turbid layer in a three dimensional sediment transport model with application to the Eel River shelf, northern California, in Estuarine and Coastal Modeling, VIII, edited by M. L. Spaulding, pp. 784-803, Waterway, Port, Coastal and Ocean Div., Am. Soc. of Civ. Eng., New York.

Hill, P. S., T. G. Milligan, and W. R. Geyer (2000), Controls on effective settling velocity of suspended sediment in the Eel River flood plume, Cont. Shelf Res., 20, 2095-2111.

Hill, P. S., G. Voulgaris, and J. H. Trowbridge (2001), Controls on floc size in a continental shelf bottom boundary layer, J. Geophys. Res., 106 , 9543-9549.

Kachel, N. B., and J. D. Smith (1986), Geological impact of sediment transporting events on the Washington continental shelf, in Shelf Sands and Sandstone, edited by R. J. Knight and J. R. McLean, Mem. Can. Soc. of Pet. Geol., 11, 145-162.

Kachel, N. B., and J. D. Smith (1989), Sediment transport and deposition on the Washington continental shelf, in Coastal Oceanography of Washington and Oregon, edited by M. R. Landry and B. M. Hickey, pp. 287-348, Elsevier, New York

Karlin, R. (1980), Sediment sources and clay mineralogy off of the Oregon coast, J. Sediment. Petrol., 50, 543-560.

Marvan, F. G., S. G. Wallis, and A. J. Mehta (2002), Episodic transport of organic-rich sediments in a microtidal estuarine system, in Fine Sediment Dynamics in the Marine Environment, edited by J. C. Winterwerp and C. Kranenburg, pp. 611-626, Elsevier, New York.

McPhee-Shaw, E. E., R. W. Sternberg, B. Mullenbach, and A. S. Ogston (2004), Observations of intermediate nepheloid layers on the northern California continental margin, Cont. Shelf Res., 24, 693-720.

Mulder, T., and J. P. M. Syvitski (1995), Turbidity currents generated at river mouths during exceptional discharge to the world oceans, J. Geol., 103, 285-298
Mullenbach, B. L., C. A. Nittrouer, P. Puig, and D. L. Orange (2004), Sediment deposition in a modern submarine canyon: Eel Canyon, northern California, Mar. Geol., 211, 101-119.

National Geophysical Data Center (2003), NGDC coastal relief model, technical report, vols. $1-8$, version 4.1.19, Boulder, Colo.

Nittrouer, C. A. (1999), STRATAFORM: overview of its design and synthesis of its results, Mar Geol, 154, 3-12.

Nittrouer, C. A., and R. W. Sternberg (1981), The formation of sedimentary strata in an allochthonous shelf environment: The Washington continental shelf, Mar Geol., 42, 201-232.

Nittrouer, C. A., and L. D. Wright (1994), Transport of particles across continental shelves, Rev. Geophys., 32(1), 85-113.

Ogston, A. S., D. A. Cacchione, R. W. Sternberg, and G. C. Kineke (2000), Observations of storm and river flood-driven sediment transport on the northern California continental shelf, Cont. Shelf Res., 20, 2141-2162.

Pullen, J., and J. S. Allen (2000), Modeling studies of the coastal circulation off northern California: Shelf response to a major Eel River flood event, Cont. Shelf Res., 20, 2213-2238.

Pullen, J., and J. S. Allen (2001), Modeling studies of the coastal circulation off northern California: Statistics and patterns of wintertime flow, J. Geophys. Res., 106, 26,959-26,984

Reed, C. W., A. W. Niedoroda, and D. J. P. Swift (1999), Modeling sediment entrainment and transport processes limited by bed armoring, Mar. Geol., 154, 143-154.

Richardson, J. F., and W. N. Zaki (1954), The sedimentation of a suspension of uniform spheres under conditions of viscous flow, Chem. Eng. Sci., 3(2), 65-73.

Ross, M. R., and A. J. Mehta (1989), On the mechanics of lutoclines and fluid mud, J. Coastal Res., 5, 51-61.

Scully, M. E., C. T. Friedrichs, and L. D. Wright (2002), Application of an analytical model of critically stratified gravity-driven sediment transport and deposition to observations from the Eel River continental shelf, northern California, Cont. Shelf Res., 22, 1951-1974.

Scully, M. E., C. T. Friedrichs, and L. D. Wright (2003), Numerical modeling of gravity-driven sediment transport and deposition on an energetic continental shelf: Eel River, northern California, J. Geophys. Res., 108(C4), 3120, doi:10.1029/2002JC001467.

Smith, J. D., and S. R. McLean (1977), Spatially averaged flow over a wavy surface, J. Geophys. Res., 82, 1735-1746.

Sommerfield, C. K., and C. A. Nittrouer (1999), Modern accumulation rates and a sediment budget for the Eel River shelf, USA: A flood-dominated depositional environment, Mar. Geol., 154, 227-241.

Sommerfield, C. K., C. A. Nittrouer, and C. R. Alexander (1999), ${ }^{7}$ Be as a tracer of flood sedimentation on the northern California continental margin, Cont. Shelf Res., 19, 335-361.

Syvitski, J. P., and M. D. Morehead (1999), Estimating river-sediment discharge to the ocean: Application to the Eel margin, northern California, Mar: Geol., 154, 13-28.

Toorman, E. A. (1998), Sedimentation and self-weight consolidation: Constitutive equations and numerical modeling, Geotechnique, 49, 709-726.

Traykovski, P. A., W. R. Geyer, J. D. Irish, and J. F. Lynch (2000), The role of wave-induced density-driven fluid mud flows for cross shelf transport on the Eel River continental shelf, Cont. Shelf Res., 20, 2113-2140.

Trowbridge, J. H., and G. C. Kineke (1994), Structure and dynamics of fluid muds on the Amazon continental shelf, J. Geophys. Res., 99, 865-874.

van Rijn, L. C. (1984), Sediment transport, part II: Suspended load transport, J. Hydraul. Eng., 110(11), 1613-1641.

Walsh, J. P., and C. A. Nittrouer (1999), Observations of sediment flux to the Eel continental slope, northern California, Mar. Geol., 154, 55-68.

Wheatcroft, R. A., and J. C. Borgeld (2000), Oceanic flood deposits on the northern California shelf: Large scale distribution and small-scale physical properties, Cont. Shelf Res., 20, 2059-2066.

Wheatcroft, R. A., C. K. Sommerfield, D. E. Drake, J. C. Borgeld, and C. A. Nittrouer (1997), Rapid and widespread dispersal of flood sediment on the northern California margin, Geology, 25, 163-166.

Winterwerp, J. C. (2002), On the flocculation and settling velocity of estuarine mud, Cont. Shelf Res., 22, 1339-1360.

Wright, L. D., S. C. Kim, and C. T. Friedrichs (1999), Across-shelf variations in bed roughness, bed stress and sediment suspension on the northern California shelf, Mar. Geol., 154, 99-115.

Zhang, Y., D. J. P. Swift, S. Fan, A. W. Niedoroda, and C. W. Reed (1999), Two-dimensional numerical modeling of storm deposition on the northern California shelf, Mar. Geol., 154, 155-167.

W. R. Geyer and P. A. Traykovski, Applied Ocean Physics and Engineering, Mail Stop 12, Woods Hole Oceanographic Institution, Woods Hole, MA 02543, USA.

C. K. Harris, Department of Physical Sciences, Virginia Institute of Marine Science, P.O. Box 1346, Gloucester Point, VA 23062, USA. (ckharris@vims.edu) 